\title{
Contemporary sediment production and transfer in high-altitude glaciers
}

\author{
Lewis A. Owen ${ }^{\text {a }}$, Edward Derbyshire ${ }^{\mathrm{b}, *}$, Christine H. Scott ${ }^{\mathrm{c}}$ \\ ${ }^{a}$ Department of Earth Sciences, University of California, Riverside, CA 92521, USA \\ ${ }^{\mathrm{b}}$ Centre for Quaternary Research, Department of Geography, Royal Holloway, University of London, Egham Surrey TW20 OEX, UK \\ ${ }^{\mathrm{c}}$ Department of Geography, University of Leicester, Leicester LE1 7RH, UK
}

Received 18 October 2001; accepted 8 March 2002

\begin{abstract}
The nature of fine-grained sediment production and transfer in high-altitude debris-covered glaciers was studied by examining the Rakhiot and Chungphar glaciers in the Nanga Parbat Himalaya, Northern Pakistan. Transport pathways, from the source areas to the glacier snout, were mapped and samples collected for particle size analysis and scanning electron microscopy. Positive down-glacier trends in sediment fining and increased weathering showed that debris transport in the supraglacial zone of these Himalayan glaciers is an important contributor to contemporary glacial sediment production, resulting in intense comminution that yields large volumes of fine sediment. These findings cast doubt on the traditional view that the basal traction zone of glaciers is the only major source of fine sediment production in glaciated environments, although that view may hold true for classic alpine glaciers that are at lower altitudes and, as a consequence, generally have less supraglacial debris cover. To test this hypothesis, the Glacier de Cheilon, in the Swiss Alps was also studied. This glacier did not exhibit such striking down-glacier trends in the particle size characteristics measured. It is thus suggested that a thick debriscover may be an important source of fine-grained sediments on glaciers that occur in high-altitude environments.
\end{abstract}

(c) 2002 Elsevier Science B.V. All rights reserved.

Keywords: Glacial sediment transport; Abrasion; Himalaya; Alpine environment; Glacial sedimentation

\section{Introduction}

In high-altitude glaciated valleys, the processes responsible for denudation of bedrock can be broadly divided into non-glacial and glacial. These processes are responsible for the breakdown of the bedrock into

\footnotetext{
* Corresponding author. Fax: +44-1273-748919.

E-mail addresses: Lewis.Owen@ucr.edu (L.A. Owen), 100666.1577@compuserve.com (E. Derbyshire).
}

erosional products, which are then transferred by fluvial, glacial, aeolian and mass movement processes within the valley system. Theories of glacial sediment transport and production have been developed on the basis of observations made on glaciers in numerous regions, including the French Alps (Boulton, 1978), the Swiss Alps (Small, 1983), Iceland (Boulton, 1978), Spitsbergen (Boulton, 1971) and British Columbia (Eyles, 1978). These authors showed that the transport of debris by glaciers involves both glacial sediment production and debris modification, and that the nature 
of the sediment produced is indicative of transport routes through the glacial systems.

Debris is available to valley glaciers from two main sources; material is derived from rock-walls above the glacier and from the bed as a result of subglacial erosion (Boulton, 1978; Kirkbride, 1995; Iverson, 1995; Benn and Evans, 1998). Debris falling on to the glacier above the equilibrium line is buried beneath successive layers of accumulating snow as it moves down-glacier. When this process occurs below the equilibrium line, the debris generally remains on the surface of the glacier to be deposited at the snout. Debris transported in the basal zone of the glacier is derived either from the bed by subglacial erosion, or indirectly from surface debris that makes its way to the bed by way of crevasses, meltwater tunnels and downward flow associated with basal melting. Such debris may remain in a basal location until it is deposited on the glacier bed or at the glacier snout. Alternatively, subglacial sediment may be transferred upwards to an englacial or supraglacial location towards the snout, in conformity with the upturning of subglacial flowlines under conditions of compressive flow, at the confluence of two glaciers, and by thrusting (Benn and Evans, 1998).

Different combinations of processes characterize these differing glacial debris transport pathways (Boulton, 1978; Kirkbride, 1995; Benn and Evans, 1998). The passage of debris through the basal zone involves large forces at non-inertial shear contacts acting upon the debris, giving rise to comminution that yields finegrained products (Boulton, 1978). Coarse mode sediments $(>0.5 \mathrm{~mm})$ are produced by crushing mechanisms while fine mode sediments $(<0.5 \mathrm{~mm})$ are the product of abrasion (Boulton, 1978). Experimental investigation of crushing and abrasion of sedimentary particles has suggested that the bulk of the fine fraction found in tills is the product of inter-clast attrition, while the coarser modes represent the products of crushing (Haldorsen, 1981). In contrast, the supraglacial system has generally been considered as a passive mode of glacial sediment transfer with little change occurring in particle size distribution or particle shape from source to glacier snout. Similarly, in the englacial zone, there are few shear contacts and few clast-on-clast contacts within the debris (Eyles, 1983; Kirkbride, 1995) because of generally low sediment concentrations. As a result, little attrition or crushing takes place, the englacial debris essentially retaining its original characteristics.

In sum, it is considered that both the form and the particle size distribution of glacially transported debris are strongly dependent upon the transport paths along which the "parent" debris has travelled. Specifically, emphasis is placed on whether the debris is transported entirely supraglacially or englacially, or whether it comes into contact with the basal zone and is subglacially transported (Boulton, 1978; Dowdeswell et al., 1985; Benn and Ballantyne, 1994; Krüger, 1994; Iverson, 1995; Benn and Evans, 1998). In consequence, fine sediments are thought to be almost solely the product of subglacial sediment transfer, with both supraglacial and englacial transfer producing debris that remains essentially unmodified during glacial transport.

However, the view that processes outside of the subglacial environment play little part in producing fine-grained sediment may not hold true for many high-altitude debris-covered glaciers, such as those in the Himalaya. Consideration of the substantial supraglacial debris loads in these environments is especially important in view of a growing body of evidence from such glaciers that supraglacial debris transport is not always a passive mechanism. Work by Humlum (1978) in the Austrian Alps, Matthews and Petch (1982) in Norway, Small (1983) in the Swiss Alps, and Kirkbride and Spedding (1996) in New Zealand suggests that, on many alpine glaciers, the balance between supraglacial and subglacial sediment production and transport appears to be different from the models underpinning current theory.

It has been shown that large quantities of finegrained sediment may be deposited or produced on the surfaces of glaciers by non-glacial processes. In particular, weathering of bedrock and rockfalls can produce a range of sediment sizes (Lautridou and Ozouf, 1984; McGreevy and Whalley, 1982; Lautridou, 1988; Smalley, 1990; Blikra and Nemec, 1998).

Fig. 1. Location of the study areas, and morphology and sampling transects for glaciers examined in this study. (A) Nanga Parbat Massif, Northern Pakistan; (B) Mt. Blanc de Cheilon, Switzerland; (C) Rakhiot glacier, northern Pakistan; (D) Chungphar glacier, northern Pakistan, and; (E) Glacier de Cheilon. 

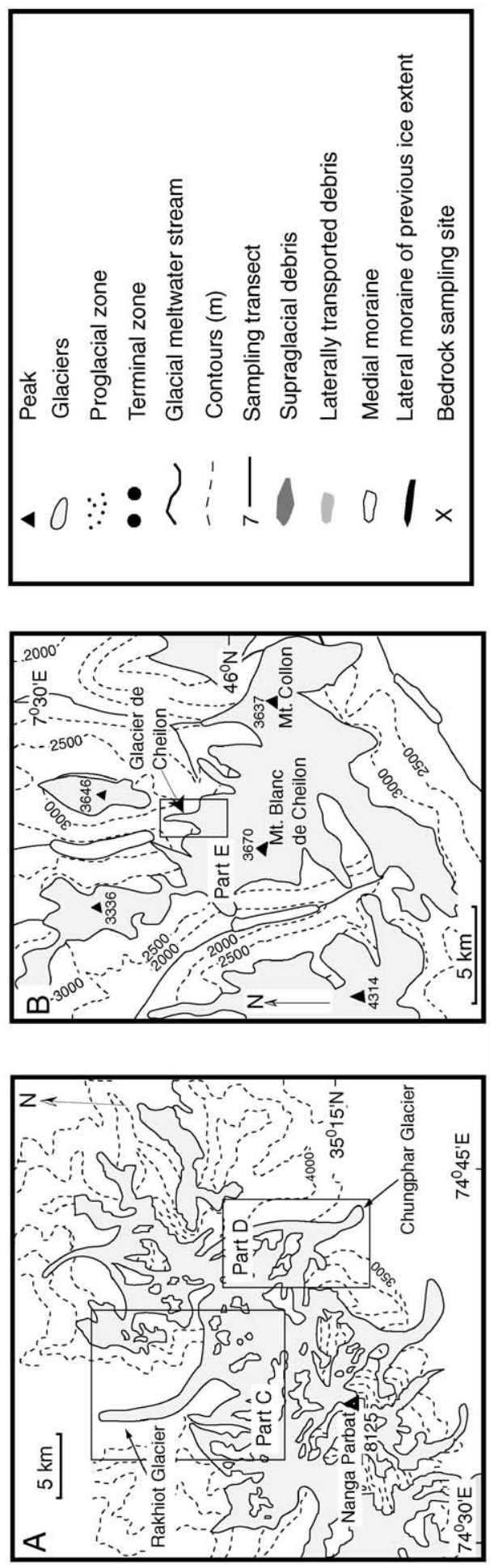
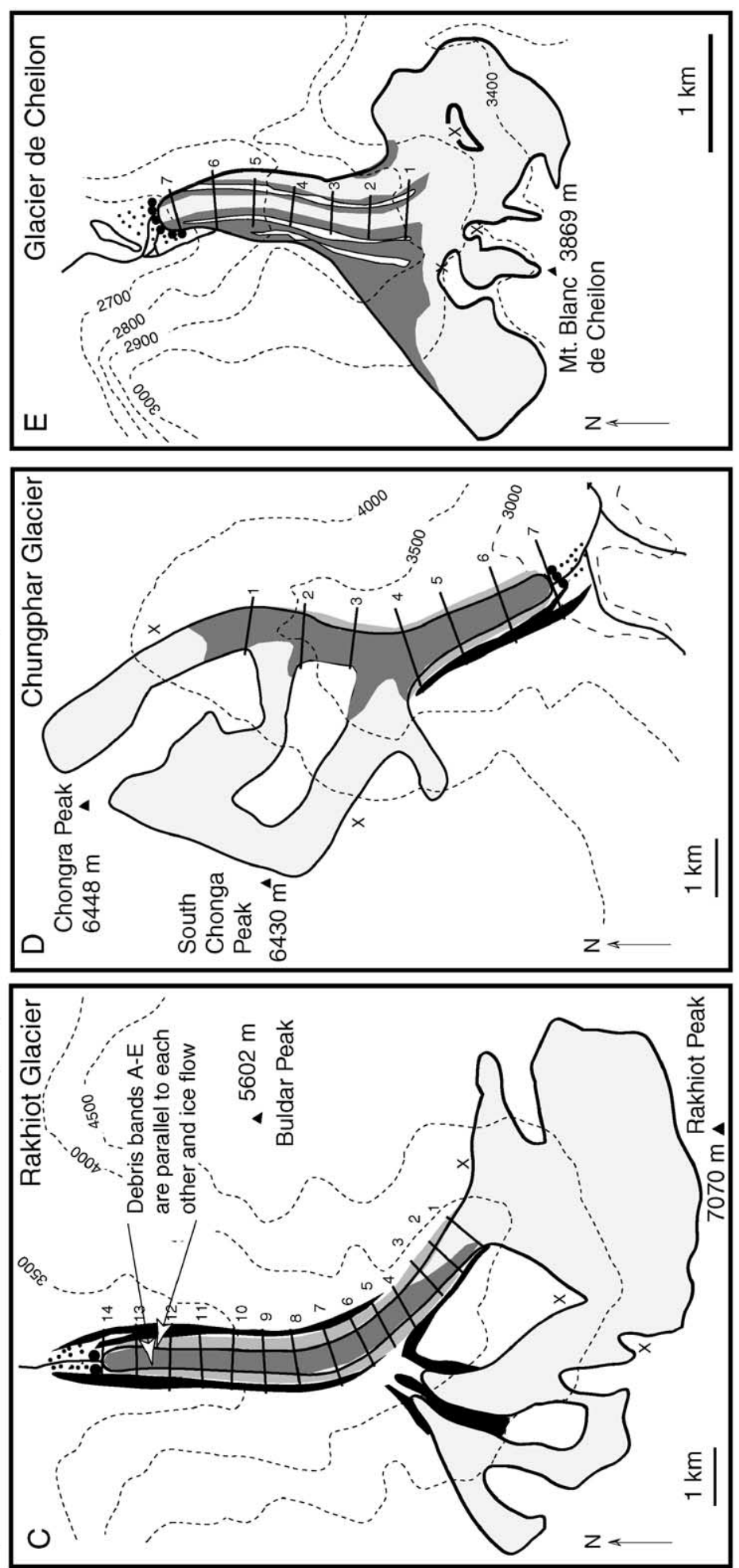
Starkel (1972), Brunsden and Jones (1984) and Hewitt $(1988,1989)$ have documented the presence of centimetre to metre-size blocky products resulting from rock weathering and rockfalls throughout the Himalaya, while Whalley (1984) and Goudie (1984) have shown that rock weathering can also produce large quantities of sand and silt. In the Karakoram Mountains, Hewitt (1988) described substantial volumes of silty-sand (between $15 \%$ and $35 \%$ ) produced when three large rock avalanches measuring $10.0 \times 10^{6}$, $7.0 \times 10^{6}$ and $3.0 \times 10^{6} \mathrm{~m}^{3}$, advanced on to the Baltoro glacier. Furthermore, in regions of high uplift and unloading, such as the Himalaya and the Alps, individual mineral grains in the abundant highly metamorphosed rocks contain numerous defects. This crystal formation is thought to enhance rock weathering, producing abundant fine-grained sediments (Moss, 1966; Moss et al., 1973; Minervin, 1984; Konischev, 1987; Gomez et al., 1988; Ritter and Mazzullo, 1990). Despite these findings, the fine sediments found in high-altitude glaciated environments continue to be attributed to subglacial abrasion.

Two Himalayan glaciers, the Rakhiot and the Chungphar, in the Nanga Parbat Himalaya of Pakistan (Fig. 1), were examined because they represent typical glaciers that are debris mantled as a consequence of the abundant debris supply by rock avalanching processes from adjacent steep slopes in a high-altitude mountain environment. A classic Swiss Alpine glacier, the Glacier de Cheilon, was also examined for comparison with the high-altitude Himalayan glaciers (Fig. 1). This glacier is characteristic of a lower-altitude mountain environment where the supply of debris to the glacier is less. This study aims to examine the nature of sediment production, transfer and modification through the supraglacial environment in two different settings: high-altitude debris-mantled glaciers, and a lower altitude glacier with moderate debris cover. We aim to test several theories of sediment production in steep highaltitude debris-covered glaciers and to highlight the importance of the supraglacial environment in sediment production and transfer.

\section{Geomorphological setting of study areas}

The Rakhiot and Chungphur glaciers are situated on the northern and southern sides, respectively, of the
Nanga Parbat massif (Figs. 1 and 2), a distinctive topographical, lithological and structural feature composed of high-metamorphic grade gneiss that rises to an altitude of $8125 \mathrm{~m}$ asl. (Wheeler et al. 1995; Seeber and Picher, 1998; Zeitler et al., 2001). The valley floors have a semi-arid climate with annual precipitation $<200 \mathrm{~mm}$ and high summer temperatures that exceed $30^{\circ} \mathrm{C}$. At heights over $4500 \mathrm{~m}$ asl, the peaks give rise to year-round orographic precipitation with annual means $>2000 \mathrm{~mm}$, most of which falls as snow (Gardner, 1985; Gardner and Jones, 1993; Kick 1962). Below $\sim 3000 \mathrm{~m}$ asl, the vegetation comprises submontane/ cool steppic (semi-arid) associations and is replaced at higher altitudes by subalpine/montane communities up to $\sim 4000 \mathrm{~m}$ asl. This is replaced, in turn, by high alpine tundra up to $\sim 5500 \mathrm{~m}$ asl where a perennial ice cover exists (Hewitt, 1989). Using Furbish and Andrews' (1984) accumulation area ratio (AAR) of 0.6 , the equilibrium line altitudes (ELAs) for the Rakhiot and Chungphur glaciers are $\sim 4800$ and $\sim 3950 \mathrm{~m}$ asl, respectively. No data are available for the ice velocity of the Chungphur glacier, but Finsterwalder (1937), Pillewizer (1956) and Shroder et al. (2000) have measured ice velocities on the Rakhiot glacier. These range from 12 to $39 \mathrm{~cm} /$ day.

The Glacier de Cheilon is situated on the northern slopes of Mont Cheilon, in the Central Alps of Valais, in the Swiss part of the Rhone Valley (Figs. 1 and 2). Mont Cheilon is made up of the high-metamorphic grade gneiss of the Dent Blanche Nappe (Escher et al., 1993). The climate is of the central-alpine dry type with an annual precipitation around $600-700 \mathrm{~mm}$ on the valley floors and $\sim 1100 \mathrm{~mm}$ at altitudes of $\sim 2300 \mathrm{~m}$ asl where the annual mean temperature is $1{ }^{\circ} \mathrm{C}$ (Roh and Rey, 1989). The upper limit of closed forest and single, well-developed trees is at 2100 and $\sim 2350 \mathrm{~m}$ asl, respectively. Based on Furbish and Andrews' (1984) AAR of 0.6, the ELA for the Glacier de Cheilon is $\sim 2900 \mathrm{~m}$ asl.

\section{Methods}

\subsection{Fieldwork and sampling}

A preliminary study of the glaciers clearly revealed glacial sediment transport pathways, that included tills on the surfaces of the glaciers, within glacier ice, 

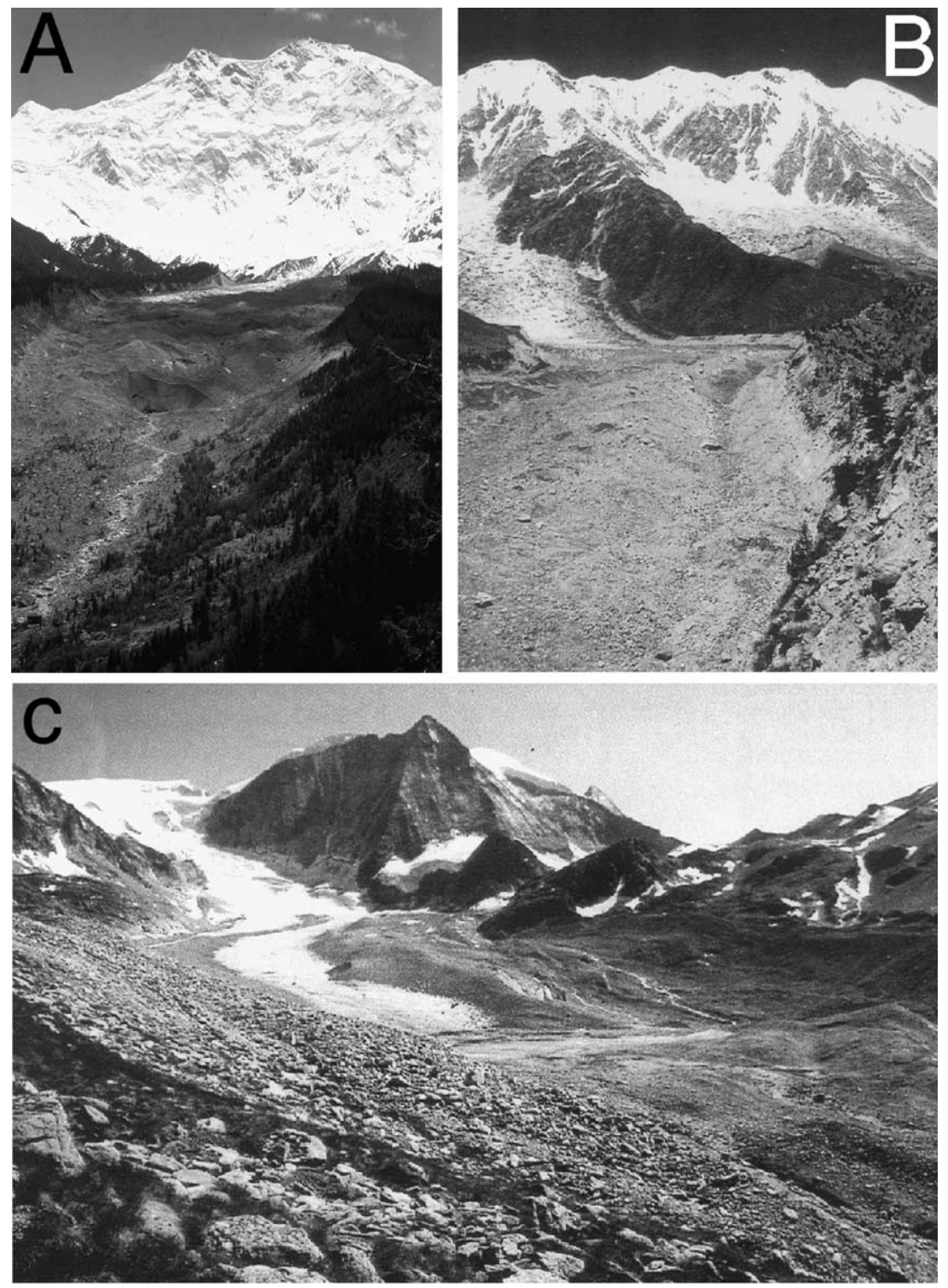

Fig. 2. Views of the glaciers examined in this study. (A) Rakhiot Glacier descending from the Rakhiot peak, $7070 \mathrm{~m}$ asl to a snout altitude of $3170 \mathrm{~m}$ asl. (B) Chungphur Glacier descending from the Chongra Peak, $6250 \mathrm{~m}$ asl to a snout altitude of $\sim 3000 \mathrm{~m}$ asl. (C) Glacier de Cheilon descending from Mt. Blanc de Cheilon, $3869 \mathrm{~m}$ asl to a snout altitude of $2650 \mathrm{~m}$ asl.

within lateral moraines and in the terminal and proglacial zones (Fig. 3). A sampling framework was constructed for the collection of glacial sediments from each of the glacial transport pathways running from the source area to the terminal zone. A series of transects was established with a regular spacing, crossing the glacier snout to an up-valley limit chosen for the practical reason that glacier gradient, icefalls or crevasses prevented further sampling (Fig. 1). Sites were located at the intersection of transport paths and each transect line. Samples from within the terminal and proglacial zones were collected from locations 


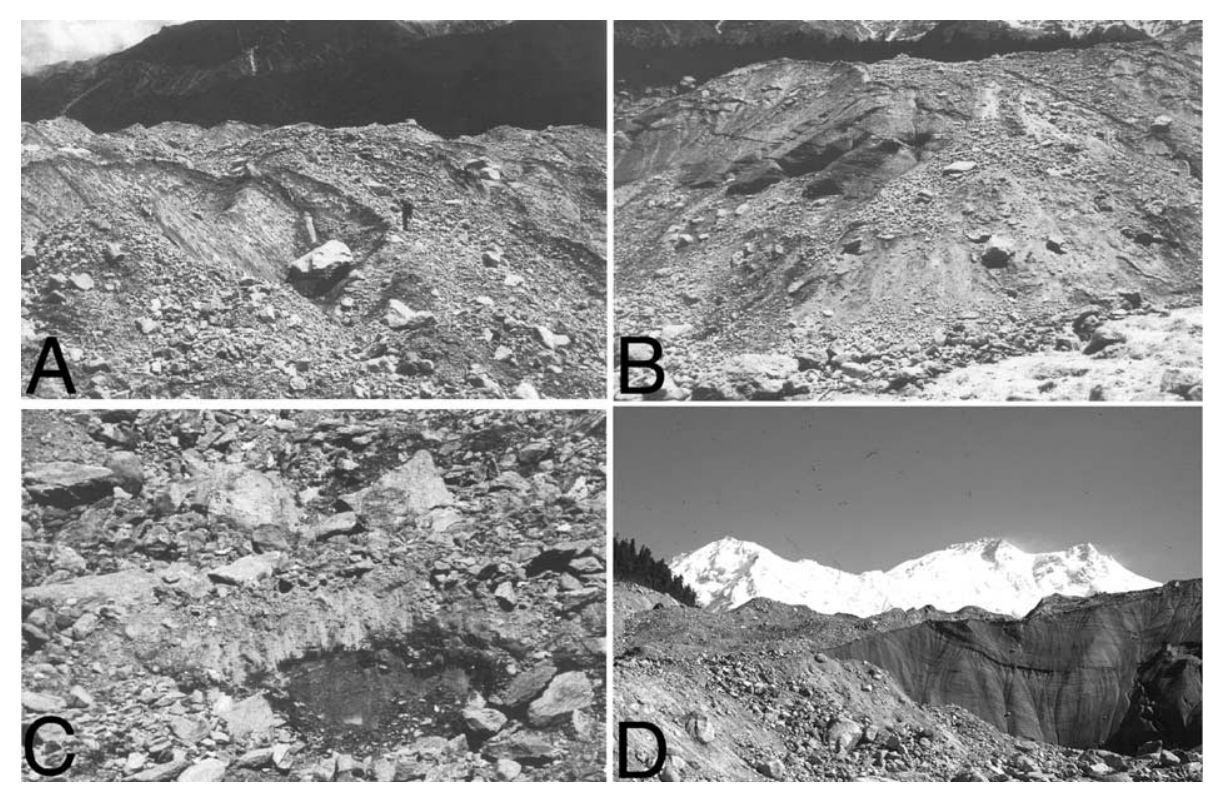

Fig. 3. Supraglacial debris on the surface of the Rakhiot Glacier. (A) Steep ice front exposed within supraglacial debris (the distance along the bottom edge of the photo is $30 \mathrm{~m}$ ). (B) Supraglacial debris being resedimentated at the snout of the Rakhiot Glacier with glaciofluvial sediment along the marines of the main glaciofluvial channel (the height of the snout in this photo is $\sim 8 \mathrm{~m}$ ). (C) Silt-rich supraglacial debris approximately $10 \mathrm{~cm}$ thick. (D) View of the snout of the Rakhiot Glacier showing meltout of supraglacial debris.

where subglacial and englacial meltout were occurring, and from desiccated proglacial ponds and glaciofluvial channels.

Bedrock and sediment samples were collected from sites on rock faces in the upper reaches of the glacier that had been identified, by field examination, as direct source areas for glacial debris. Sediment derived from weathered bedrock that had accumulated within fractures behind the exposed rock surface was collected from locations near the glacier. This material is regarded as a representative weathering product because opportunity for sediment from 'external' sources to be deposited behind the rock face can be excluded. Furthermore, the likelihood of the samples having been subjected to significant modification while in transit from source to depositional site on the glacier was minimized by collecting from locations very close to the glacier.

Some 210 measurements were made of the supraglacial sediment thickness by digging vertical sections through the sediment down to the surface of the Rakhiot glacier at the sampling sites, as well as at some intermediate points.

\subsection{Particle size analysis}

A $0.5-\mathrm{kg}$ sample of glacial sediment was obtained from each site from within $10-20 \mathrm{~cm}$ of the surface using the methods described by Gale and Hoare (1991) and Lindholm (1987). These were then split, using a riffle box in the field, to obtain a representative sample. Only material finer than $5 \mathrm{~mm}$ was collected for laboratory analysis. This upper particle size limit was chosen because it ensures that subsequent sieving of the material in the laboratory retains the whole of the $<4-\mathrm{mm}$ fraction. This maximum diameter was chosen in accordance with the engineering convention of Lindholm (1987). Material coarser than $5 \mathrm{~mm}$ in diameter was classified in the field at each sampling location on the basis of particle size using a tape measure (Wentworth, 1922). The particle size distribution of each sample, from $4 \mathrm{~mm}$ to $63 \mu \mathrm{m}$, was determined in the laboratory by a combination of wet and dry sieving (BS 1377 British Standards Institution 1967) using half grade (Ø) intervals in mesh size between sieves, following the techniques of Allen (1981). X-ray size sorting of the fraction 
smaller than $63 \mu \mathrm{m}$ was carried out using a Micromeritics 5100 ET SediGraph (Gale and Hoare, 1991).

\subsection{Particle shape analysis}

Particles finer than coarse sand in the Rakhiot samples were examined using a scanning electron microscope (SEM). Single particles of silt and sand were prepared by washing in dilute hydrochloric acid $(0.1 \%)$ to dissolve carbonates and iron deposits. The sample was then rinsed with de-ionized water, placed in a solution of $0.1 \%$ dispersing agent ('Calgon') and left in an ultrasonic bath for up to 10 minutes to effect disaggregation and detachment of any clays from the particles, so producing clean grain surfaces for microscopic examination. Repeated washing of the remaining particles using de-ionized water left nonaggregated single particles with clean faces; these were examined under the SEM. The shape and weathering characteristics of 100 particles per sample were determined. A sample of 100 particles was considered statistically valid because it is well over 10 times the number of classes considered for each set of characteristics. Care was taken that all measurements were made on quartz particles using the EDAX attachment on the SEM to confirm the particle mineralogy. Powers' (1953) visual estimation charts for roundness and Zingg's (1935) classification for sphericity were used to determine the shape of each sand-size quartz particle, taking advantage of the three-dimensional viewing facility of the SEM. It is recognized that these older techniques are simple in comparison with some now used for measuring the particle shape of glaciogenic grains (e.g. Benn and Ballantyne, 1993, 1994). However, although these newer measures are readily applied to grains coarser than the sand grade, they pose practical difficulties when measuring large numbers of sand and silt grains under the microscope. The simpler measures used here also offer the advantage of facilitating rapid examination of large sample numbers. Moreover, the small number of categories used in each descriptive measure allows changes in particle shape to be readily determined.

\subsection{Particle weathering}

Surface weathering ratios were recorded using visual estimation charts from Sheridan and Marshall
(1987). Individual grains were assigned to one of six weathered surface categories, namely $0-10 \%, 10-$ $30 \%, 30-50 \%, 50-60 \%, 60-80 \%$ and $80-100 \%$ of the particle's surface is weathered. The mean value of the percentage-weathered surface was calculated for each sample.

Photographs were taken of random sample sets as a means of checking the accuracy of the measurements made directly from SEM observations. The area of weathered surface was calculated from these photographs in order to test the accuracy of the visual estimations, and the roundness and sphericity were also estimated using SEM stereo-pairs of selected samples. These two sets of techniques produced consistent results from independent work by the coauthors, although the nature of these internal checks precludes any quantification of reproducibility.

\section{Results}

\subsection{Particle size analysis}

Table 1 summarizes the range of particle size distributions for the sediments from each glacier, in the form of weight percentage of silt and sand content.

\subsubsection{Glacially transported sediments}

Fig. 4 shows the 50 th percentile (median, $D_{50}$ ) values for the particle size distributions of the glacially transported sediments of the Rakhiot glacier for (A) supraglacially transported sediments and (B) laterally transported sediments. Sediments from the supraglacial transport paths were found to be marginally coarser than sediments in the inner lateral transport path and the outer ice-cored lateral path. The supraglacially transported sediments become finer down-glacier as far as transect 9 with the $\mathrm{D}_{50}$ particle sizes decreasing from over $1000 \mu \mathrm{m}$ at transect 1 , to less than $750 \mu \mathrm{m}$ at transect 9. Each transport route gives high least-squared regression values $\left(r^{2}\right.$ : Fig. 4A). Beyond transect 10, the particle sizes fluctuate and actually increase. Down-glacier fining is not as evident in the sediments of the inner and outer laterals. Although $\mathrm{D}_{50}$ values decline as far as transects 7 and 8 , there is no clear trend further down. The range of variation in values is greater in the western laterals than in the eastern ones, which remain fairly 
Table 1

Ranges for percentage values by weight for silt and sand content for sediments from the Rakhiot and Chungphar glaciers and the Glacier de Cheillon

\begin{tabular}{|c|c|c|c|c|c|c|c|c|c|c|c|c|c|c|c|c|}
\hline \multirow{2}{*}{$\begin{array}{l}\text { Glacial } \\
\text { environment }^{\mathrm{a}}\end{array}$} & \multirow{2}{*}{$\begin{array}{l}\text { Number } \\
\text { of samples }\end{array}$} & \multicolumn{4}{|c|}{ Rakhiot glacier } & \multirow{2}{*}{$\begin{array}{l}\text { Number } \\
\text { of samples }\end{array}$} & \multicolumn{4}{|c|}{ Chungphar glacier } & & \multirow{2}{*}{$\begin{array}{l}\text { Number } \\
\text { of samples }\end{array}$} & \multicolumn{4}{|c|}{ Glacier de Cheillon } \\
\hline & & $\begin{array}{l}\text { Min. } \\
\text { silt } \\
(\%)\end{array}$ & $\begin{array}{l}\text { Max. } \\
\text { silt } \\
(\%)\end{array}$ & $\begin{array}{l}\text { Min. } \\
\text { sand } \\
(\%)\end{array}$ & $\begin{array}{l}\text { Max. } \\
\text { sand } \\
(\%)\end{array}$ & & $\begin{array}{l}\text { Min. } \\
\text { silt } \\
(\%)\end{array}$ & $\begin{array}{l}\text { Max. } \\
\text { silt } \\
(\%)\end{array}$ & $\begin{array}{l}\text { Min. } \\
\text { sand } \\
(\%)\end{array}$ & $\begin{array}{l}\text { Max. } \\
\text { sand } \\
(\%)\end{array}$ & & & $\begin{array}{l}\text { Min. } \\
\text { silt } \\
(\%)\end{array}$ & $\begin{array}{l}\text { Max. } \\
\text { silt } \\
(\%)\end{array}$ & $\begin{array}{l}\text { Min. } \\
\text { sand } \\
(\%)\end{array}$ & $\begin{array}{l}\text { Max. } \\
\text { sand } \\
(\%)\end{array}$ \\
\hline \multicolumn{17}{|l|}{ Glacial } \\
\hline Supraglacial & 65 & 0.68 & 8.76 & 45.51 & 78.38 & 14 & 3.27 & 14.63 & 42.29 & 75.08 & $\begin{array}{l}\text { Supraglacial } \\
\text { fluvial }\end{array}$ & 8 & 0.00 & 4.82 & 31.38 & 60.18 \\
\hline Inner moraine & 28 & 4.87 & 16.54 & 39.29 & 81.41 & 14 & 7.45 & 19.36 & 38.85 & 75.97 & $\begin{array}{l}\text { Supraglacial } \\
\text { meltout }\end{array}$ & 7 & 0.66 & 5.54 & 36.90 & 56.85 \\
\hline Outer moraine & 28 & 3.76 & 10.86 & 49.56 & 80.27 & 14 & 4.27 & 15.13 & 45.50 & 76.24 & East medial & 7 & 0.00 & 11.14 & 24.85 & 74.79 \\
\hline $\begin{array}{l}\text { Accumulation } \\
\text { channel }\end{array}$ & 8 & 8.64 & 61.43 & 12.81 & 86.62 & 5 & 10.27 & 59.44 & 6.84 & 88.52 & West medial & 7 & 0.00 & 7.61 & 33.98 & 70.09 \\
\hline \multicolumn{17}{|l|}{ Terminoglacial } \\
\hline $\begin{array}{l}\text { Supraglacial } \\
\text { fluvial }\end{array}$ & 6 & 2.98 & 11.30 & 47.40 & 97.20 & & & & & & & 6 & 1.16 & 28.51 & 11.76 & 97.70 \\
\hline $\begin{array}{c}\text { Supraglacial } \\
\text { melt-out }\end{array}$ & 10 & 3.21 & 11.45 & 50.35 & 74.80 & 4 & 6.17 & 18.34 & 51.71 & 75.14 & & 6 & 15.32 & 52.72 & 0 & 82.41 \\
\hline $\begin{array}{l}\text { Subglacial } \\
\text { fluvial }\end{array}$ & 10 & 3.94 & 41.88 & 8.32 & 90.73 & 4 & 8.55 & 27.79 & 30.49 & 85.80 & & 5 & 13.06 & 47.74 & 0 & 85.80 \\
\hline $\begin{array}{r}\text { Subglacial } \\
\text { melt-out }\end{array}$ & 8 & 15.45 & 40.41 & 35.33 & 83.29 & 4 & 20.37 & 41.18 & 48.85 & 79.63 & & 5 & 2.15 & 13.28 & 41.94 & 89.90 \\
\hline Englacial & & & & & & & & & & & & 5 & 6.04 & 20.86 & 33.76 & 80.12 \\
\hline \multicolumn{17}{|l|}{ Proglacial } \\
\hline Glaciofluvial & 6 & 2.35 & 5.05 & 72.75 & 95.79 & 3 & 8.48 & 13.62 & 52.11 & 90.33 & & 5 & 7.56 & 46.45 & 13.81 & 90.63 \\
\hline Glaciolacustrine & 10 & 10.73 & 40.30 & 57.90 & 88.85 & 3 & 14.30 & 37.15 & 53.51 & 85.70 & & 4 & 53.31 & 78.99 & 19.10 & 46.69 \\
\hline Ice melt-out & 8 & 6.55 & 11.05 & 50.10 & 79.49 & 3 & 12.19 & 17.84 & 46.58 & 82.38 & & 4 & 2.21 & 29.68 & 35.16 & 96.75 \\
\hline Non-glacial & 9 & 10.82 & 37.34 & 28.01 & 84.00 & 4 & 18.97 & 39.11 & 33.66 & 75.48 & & 3 & 3.04 & 4.17 & 32.34 & 55.47 \\
\hline
\end{tabular}

${ }^{\text {a }}$ This environment refers to the ablation zone and includes all the sampling transect (Fig. 1), but excludes the terminal areas of the glaciers shown in Fig. 1. 

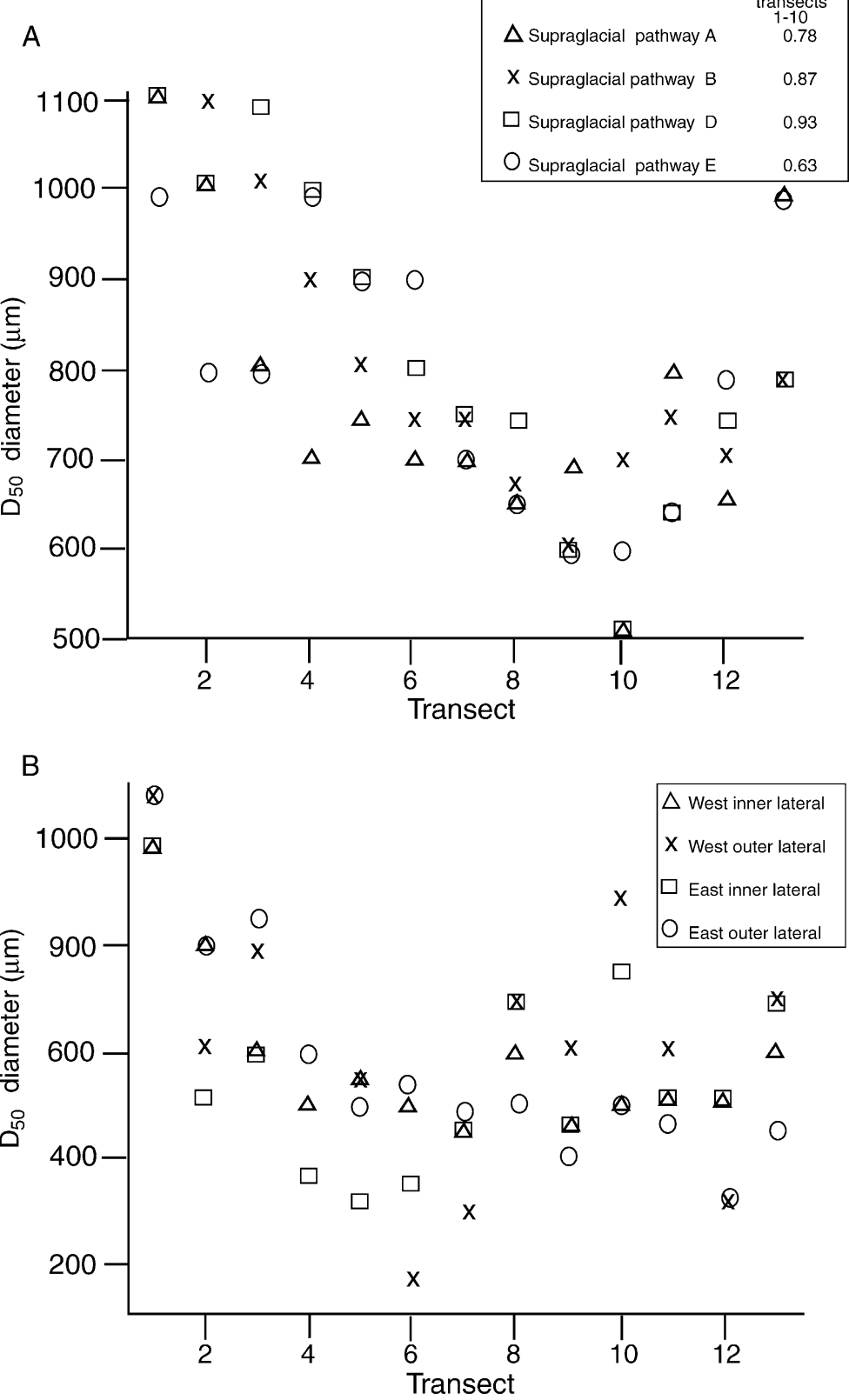

Fig. 4. Down-glacier 50th percentile $\left(\mathrm{D}_{50}\right)$ values for supraglacial sediments from the Rakhiot glacier in: (A) five supraglacial pathways labeled $\mathrm{A}, \mathrm{B}, \mathrm{D}$ and E, and; (B) lateral transport pathways. The least-squared regression values are shown for $\mathrm{D}_{50}$ values for sediment sampled along the supraglacial pathways between transects 1 and 10 to illustrate the positive correlation down glacier. Least-squared regression values are not shown for lateral transport pathways because there are no significant trends.

constant below transect 8 . As field conditions appeared similar for both sets of laterals, no explanation of this difference is immediately evident.
The percentages of fine sediment for five supraglacial debris transport paths $(\mathrm{A}-\mathrm{E})$ on the Rakhiot glacier are shown in Fig. 5. The percentage of silt 
A
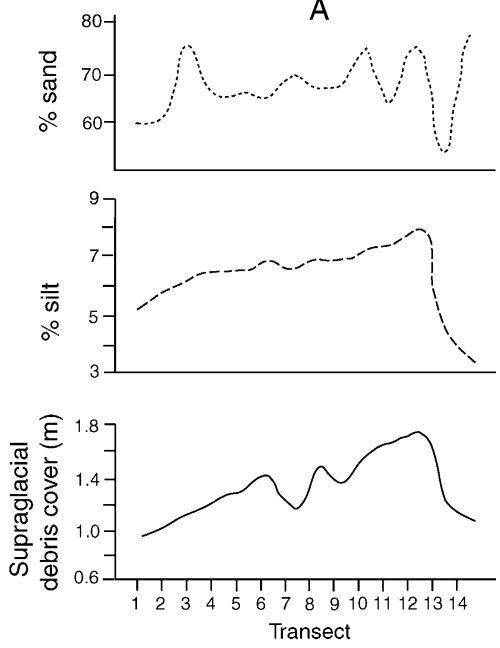

D
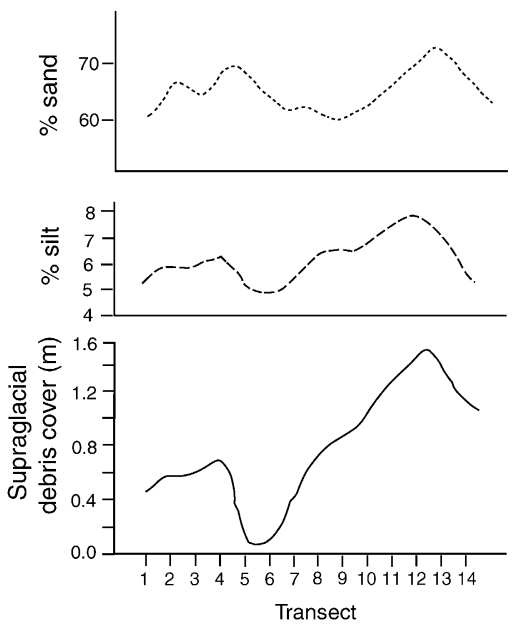

B
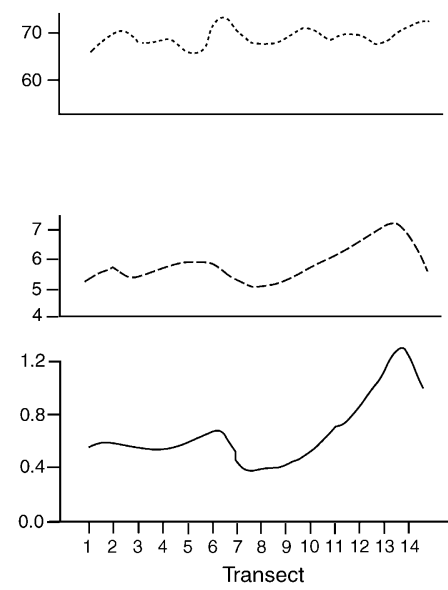

E
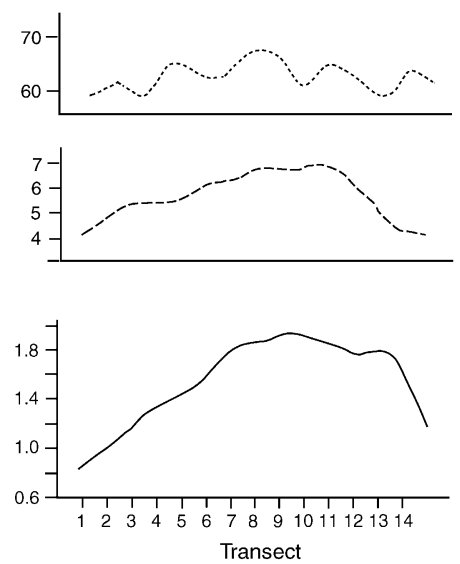

C
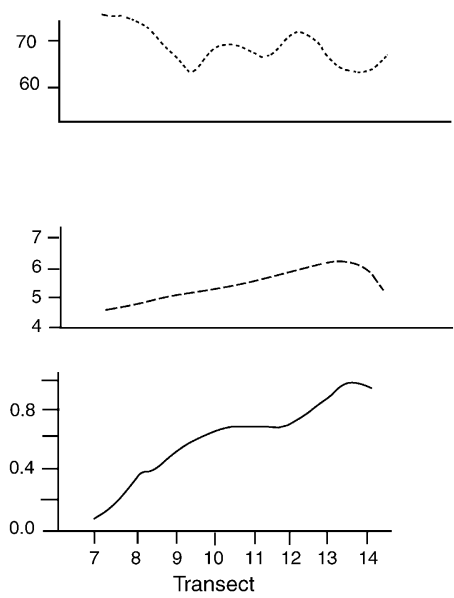

Mean values for transects $A$ to $E$
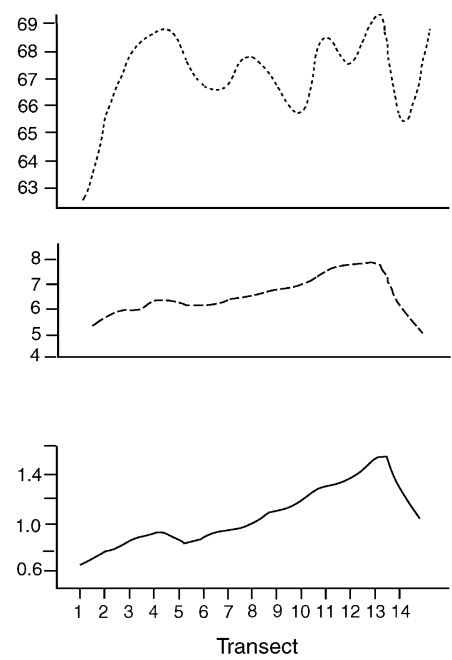

Fig. 5. Percentage values of silt and sand along five supraglacial debris pathways $\mathrm{A}-\mathrm{E}$ and the mean values for pathways $\mathrm{A}-\mathrm{E}$ at transects 1-14 down the Rakhiot glacier. Debris-cover thickness is also shown.

shows a fluctuating, but general increase in all transport paths with distance down-glacier as far as transect 12 . The percentage sand content is more variable, with greater fluctuations and, in contrast to the silt results, no down-glacier increase is evident. A steep decrease in percentage values of silt occurs below transect 12 . This may reflect the observed fact that meltwater increasingly removes fine sediments from the glacier below transect 12 .

The down-glacier variation in sediment characteristics within each zone of the Chungphar glacier was not examined in as much detail, but percentage silt content in the supraglacial debris of both inner and outer moraines is similar (Table 1).

Accumulations of finer sediments were found to exist in small meltwater channels in both the Rakhiot and Chungphar glaciers. These channels were less than $0.5 \mathrm{~m}$ wide, running between the inner and outer laterals. Although not included in the sampling framework, samples of this material showed them to be exceptionally rich in fines (Table 1). Finally, all the glacially transported sediments were found to contain 
extremely low percentages of clay-grade material $(\sim 3 \%)$.

Sediments transported by the Glacier de Cheilon in the European Alps are coarser than those on the Rakhiot and Chungphar glaciers, having silt contents $<12 \%$ (Table 1). No down-glacier trend is evident in the lateral populations, although least-squared regression values and Pearson product moment correlation using $\mathrm{D}_{50}$ values (Table 2 ) suggest a modest degree of down-glacier fining in the supraglacial debris (Fig. 6).

\subsubsection{Terminal zone sediments}

In the terminal zones of the Rakhiot and Chungphar glaciers, sediments are currently being deposited subglacially and supraglacially by meltout and glaciofluvial processes. This renders field identification and sampling of the different types relatively easy. The particle size characteristics show that subglacial sediments contain more silt and show greater variation in particle size distribution compared to supraglacial sediments. The Rakhiot subglacial fluvial sediments show the broadest distributional ranges (fine sediments with few coarse particles to sandy sediments containing few fines). In contrast, the supraglacial sediments have narrow particle-size distribution ranges, being coarser than the subglacial meltout sediments. Percentage clay-grade material is negligible. No supraglacial fluvial deposits were found on the Chungphar glacier.

In contrast, the finer sediment fractions are more abundant in the terminal zone of the Glacier de Cheilon, suggesting some incorporation of basal sedi-

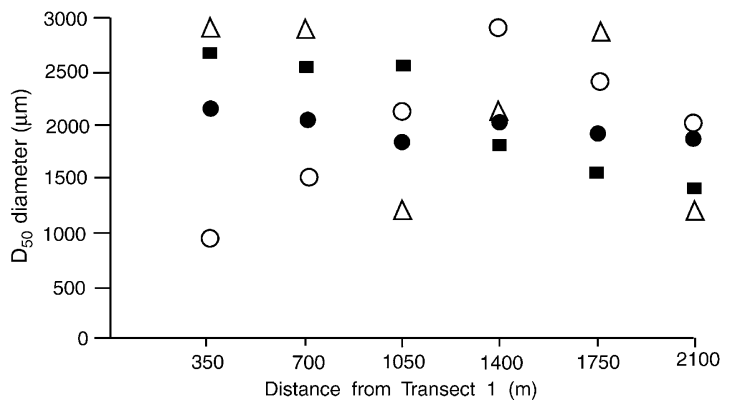

Fig. 6. Down-glacier 50th percentile $\left(\mathrm{D}_{50}\right)$ values for glacial transported sediments of the Glacier de Cheilon, Swiss Alps. Leastsquared regression values are as follows: supraglacial fluvial 0.68 ; supraglacial non-fluvial 0.93; west lateral 0.24; and east lateral 0.47. Pearson product moment correlation coefficients of changes in $\mathrm{D}_{50}$ values with distance down glacier are as follows: supraglacial fluvial -0.82 ; supraglacial non-fluvial -0.96 ; west lateral -0.49 ; and east lateral 0.69 .

ments (Table 1). In agreement with results from previous studies of similar European Alpine glaciers (Boulton, 1978; Small, 1983), the subglacial sediments contain high percentages of silt and sand. Supraglacial fluvial sediments are the coarsest, suggesting fine-grained sediment depletion by glacial meltwaters across the glacier snout.

\subsubsection{Proglacial sediments}

The finest materials in the proglacial zones of the Rakhiot and Chungphar glaciers are of glaciolacustrine origin, those of the Rakhiot glacier having a silt content of up to $40 \%$, with up to $37 \%$ for the Chungphar glacier (Table 1). All show great variations

Table 2

Pearson product moment correlation coefficients for quartz sand grain shape versus glacier transect number, and least squared regression values for three debris facies on the Rakhiot glacier (cf. Fig. 10)

\begin{tabular}{|c|c|c|c|c|c|}
\hline Debris facies & Very angular & Angular & Sub-angular & Sub-rounded & Rounded \\
\hline \multicolumn{6}{|l|}{ Supraglacial } \\
\hline Pearson & 0.9333 & -0.0189 & -0.8023 & 0.79 & 0.6093 \\
\hline$R^{2}$ & 0.871 & 0.0004 & 0.6437 & 0.624 & 0.3713 \\
\hline \multicolumn{6}{|l|}{ Inner lateral } \\
\hline Pearson & 0.7824 & 0.8172 & -0.872 & -0.0079 & $\mathrm{n} / \mathrm{a}$ \\
\hline$R^{2}$ & 0.6122 & 0.6679 & 0.7604 & 0 & $\mathrm{n} / \mathrm{a}$ \\
\hline \multicolumn{6}{|l|}{ Outer lateral } \\
\hline Pearson & 0.5352 & 0.69 & -0.9481 & 0.3967 & 0.8624 \\
\hline$R^{2}$ & 0.2864 & 0.4761 & 0.899 & 0.1574 & 0.7437 \\
\hline
\end{tabular}


in silt content, but all samples contain over $57 \%$ and $53 \%$ sand-sized particles, respectively (Table 1). In fact, most of these glaciolacustrine sediments lie in the medium-sand to silt size range. Both the glaciofluvial and the supraglacial meltout sediments are much coarser, the latter being coarser than the former. The proglacial sediments of the Glacier de Cheilon have high silt contents $(\sim 30-79 \%$, Table 1$)$, the glaciolacustrine sediments showing a narrow particle size envelope with high percentage silt contents of between $53 \%$ and $79 \%$.

\subsubsection{Non-glacially produced sediments}

Particle size distribution envelopes for samples of sediments produced by weathering processes within fractures on the high rock-walls above the Rakhiot and Chungphar glaciers are shown in Fig. 7. The proportion of fine sediment present, represented by the range of silt content, is high in both glacial systems, with silt contents between $10 \%$ and $37 \%$ for the Rakhiot glacier and $18 \%$ to $39 \%$ for the Chungphar (Fig. 7 and Table 1). In the case of the Rakhiot glacier, the coarse silt and fine sand content is less, with proportionately more material of medium and coarse sand grade. In general, the percentage content of sand ranges quite widely, being similar in both systems (Table 1).

Samples of the sediments from within fissures in weathered bedrock on high rock-walls above the Glacier de Cheilon have a relatively narrower range of coarse particle sizes with very low percentages of silt grains $(<5 \%)$ (Table 1$)$. Compared to the two Nanga Parbat glaciers, the sand percentages are also very low ( $=56 \%$ : Table 1$)$. Although the Glacier de Cheilon and Nanga Parbat catchment areas are underlaid by similar lithologies, they have slightly different climatic and geomorphic characteristics that are likely to cause differences in the nature and rates of weathering between these two settings.

\subsubsection{Comparison between the sediments of each zone}

In the Rakhiot and Chungphar glacial catchment areas, supraglacial sediments have silt and sand

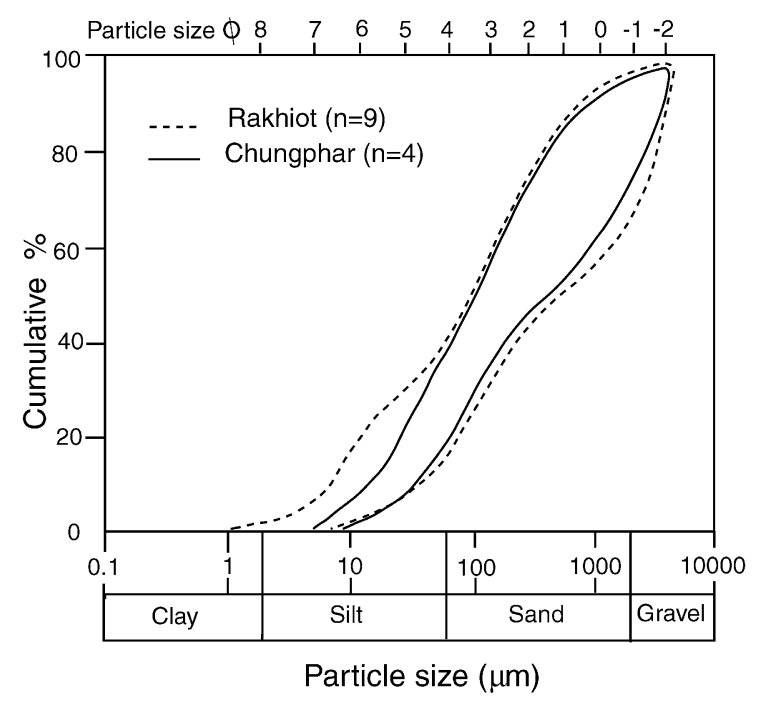

Fig. 7. Particle-size distribution envelops for non-glacially produced sediment for the Rakhiot and Chungphar glaciers $(n=$ number of samples).

maxima that range between $\sim 8-14 \%$ and $\sim 75-$ $78 \%$, respectively (Table 1 ), while non-glacially derived sediments have high percentages of silt and sand maxima ( $\sim 37-39 \%$ and $75-84 \%$, respectively: Table 1 and Fig. 7). The highest silt percentages are found in the lacustrine, supraglacial accumulation channels, and subglacial meltout populations (Table 1). For the Glacier de Cheilon, the percentage maxima for silt $(\sim 4-11 \%)$ and sand $(\sim 56-74 \%)$ in supraglacial and lateral moraine sediments are clearly lower than in sediments produced in the terminal and proglacial zones (silt maxima 13-78\%, sand maxima 46-97\%: Table 1). As noted above, the maximum percentage of silt $(\sim 4 \%)$ and sand $(\sim 56 \%)$ produced in the nonglacial environment is less than in the Nanga Parbat area (Table 1).

The mean particle size distributions of the supraglacial and subglacial sediments for all three glaciers are shown in Fig. 8. Some strong contrasts are evident. For example, the supraglacial sediments

Fig. 8. Mean weight percentages per $1 / 2 \phi$ interval of (A) supraglacial and (B) subglacial debris from the Rakhiot and Chungphur glaciers and from the Glacier de Cheilon, with selected comparisons. Sample numbers of supraglacial sediments for the Rakhiot and Chungphar glaciers and the Glacier de Cheilon are 65, 14 and 8, respectively. Subglacial sediment sample numbers for the Rakhiot and Chungphar glaciers and the Glacier de Cheilon are 18, 8 and 10, respectively. 

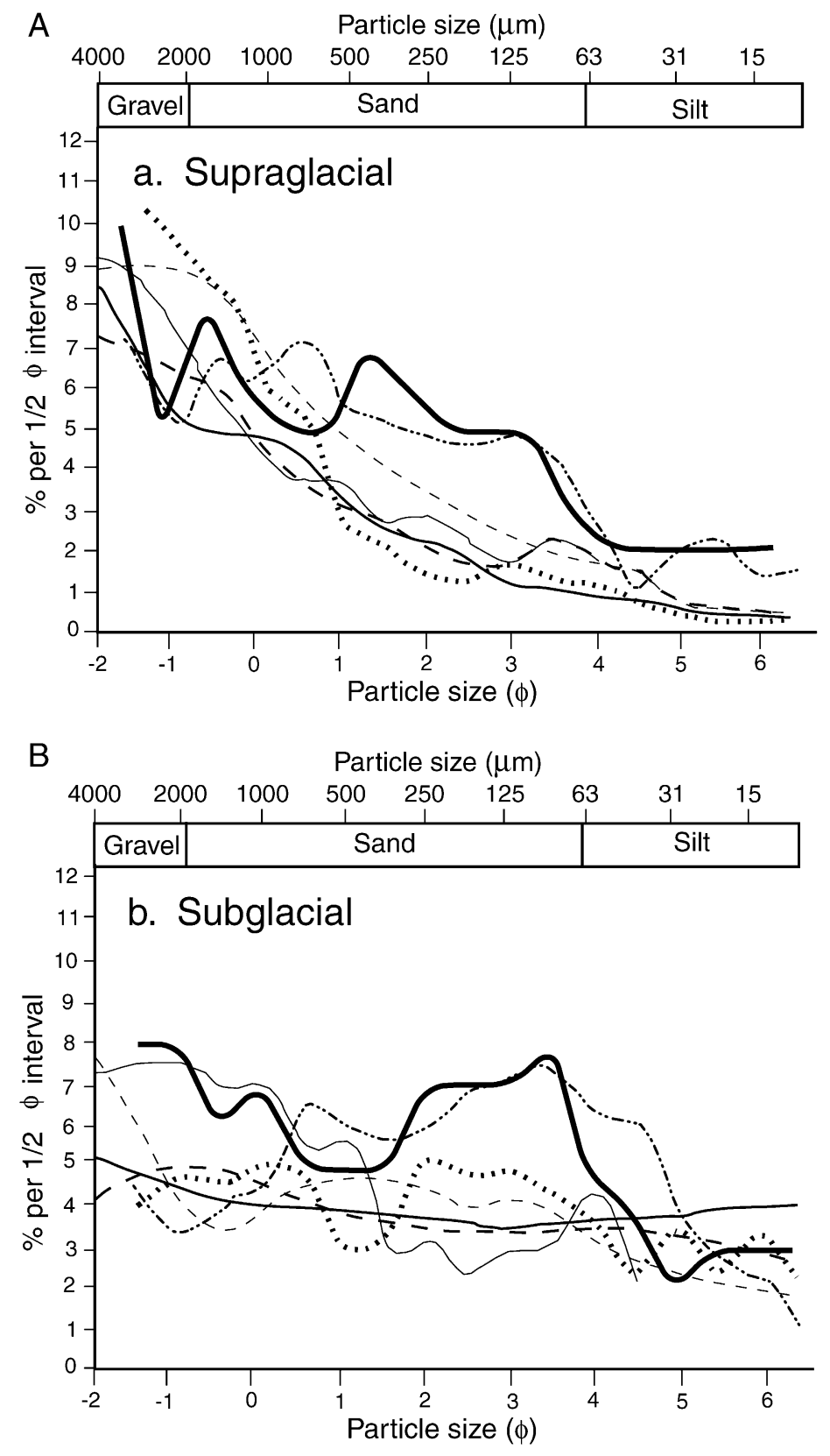

— Breidamerkurjokkull, Boulton $1978 \quad$.... $\quad$ Rakhiot glacier

- Sore Buchananisen, Boulton $1978 \quad$ Chungphar glacier

- - Glacier d'Argentiere, Boulton $1978 \quad$ …' Glacier de Cheillon

__ Glacier de Tsidijore Nourve, Small 1983 
contain high gravel $(\lessgtr 1 \varnothing)$ and coarse sand (1.5 to $\sim 0.5 \varnothing$ ) percentages, with very low values for coarse silt (4 to $5 \varnothing$ ). In contrast, the subglacial sediments are poorer in gravel and coarse sand size $(<0.5 \varnothing)$ with the bulk of the material lying in the medium sand, fine sand and coarse silt ranges.
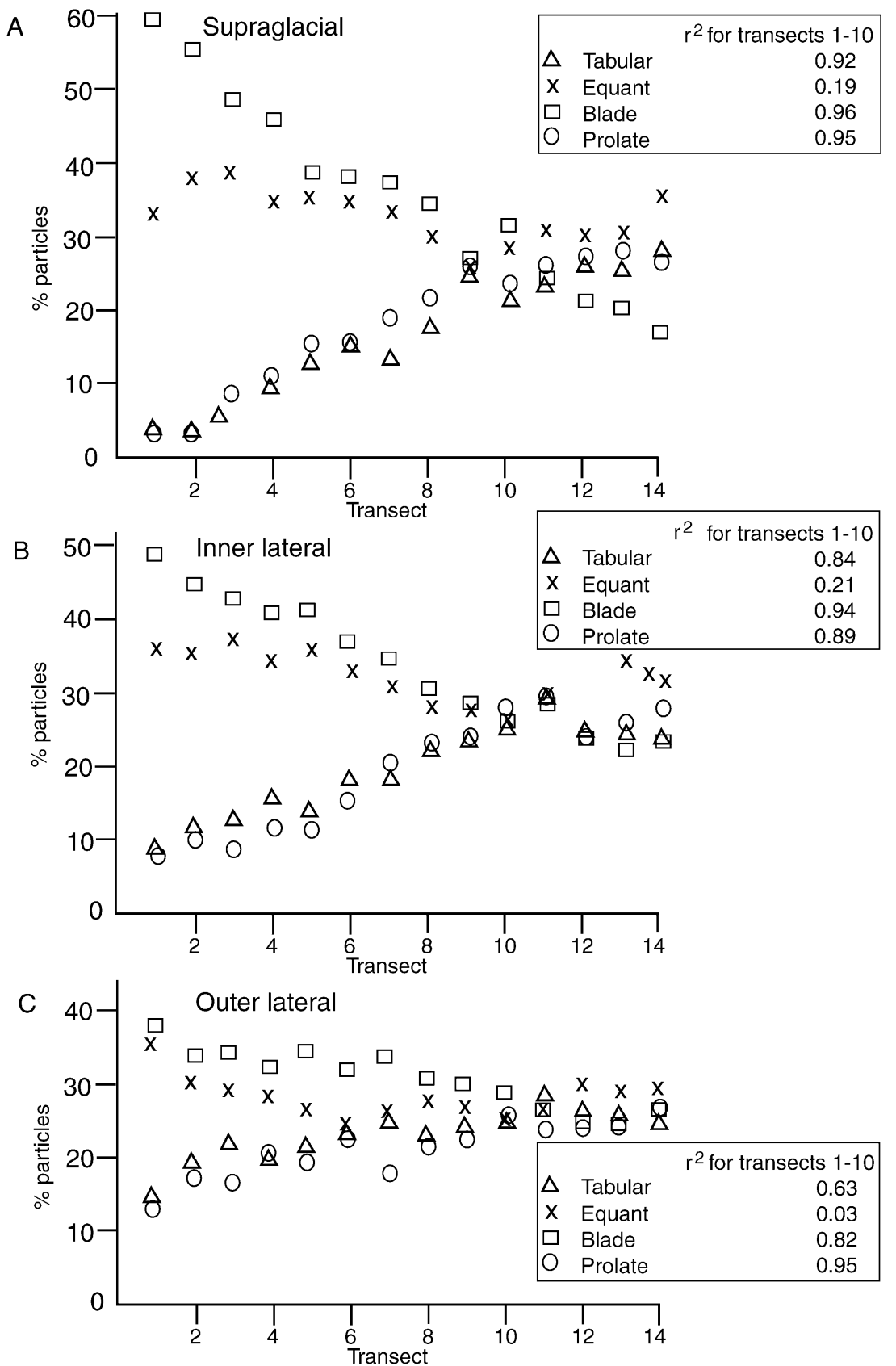

Fig. 9. Down-glacier changes in the sphericity of glacially transported sand size quartz particles on the Rakhiot glacier for (A) supraglacial debris, (B) inner lateral moraine sediments and (C) outer lateral moraine sediments. Grain size shape categories are according to Zingg (1935). 


\subsubsection{Comparison with previous work from other} glacial systems

Using Fig. 8, a comparison may be made between the mean particle size distributions of the supraglacial and subglacial sediments obtained during this study and similar sediments taken from glaciers in the French Alps, Spitsbergen and Iceland (Boulton, 1978) and from the Swiss Alps (Small, 1983). In the case of the supraglacially transported sediments, the Rakhiot and Chungphar materials are clearly finer than those found in the other systems. For example,
Rakhiot supraglacial sediments are poorer in coarse sand and gravel than the Glacier d'Argentiere (Boulton, 1978), the Glacier de Tsidjiore Nouve (Small, 1983 ) and the Sore Buchananisen (Boulton, 1978), the supraglacial covers of which are dominated by sand and gravel. Not surprisingly, the mean particle size of the Glacier de Cheilon supraglacial sediments is very similar to results obtained in previous studies. In the case of the subglacial sediments, the Rakhiot and Chungphar glaciers are richer in fine sand and silt compared to the glacier systems cited above, with the

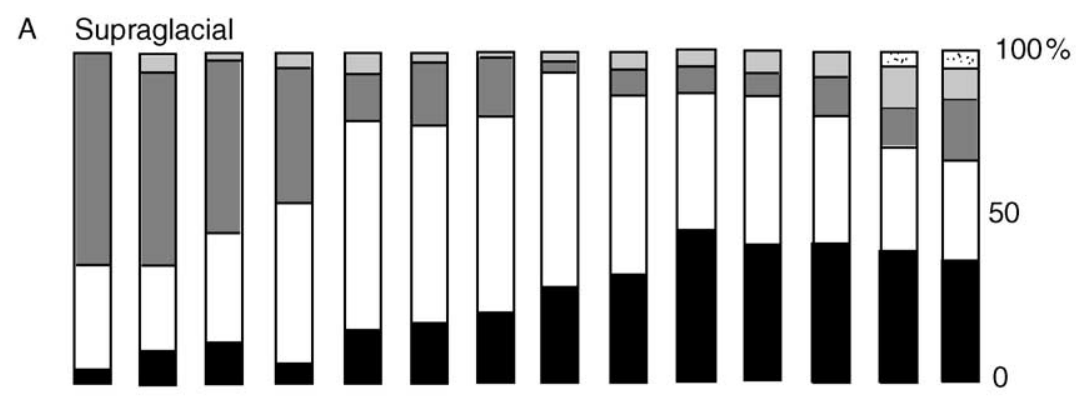

B Inner lateral

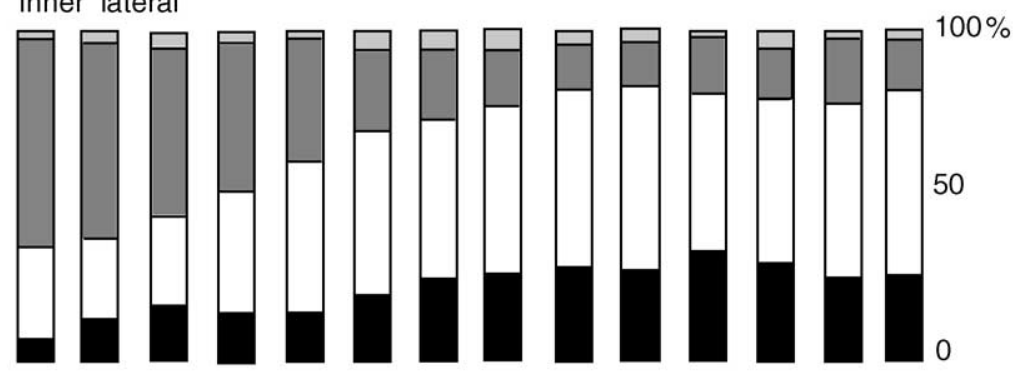

C Outer lateral

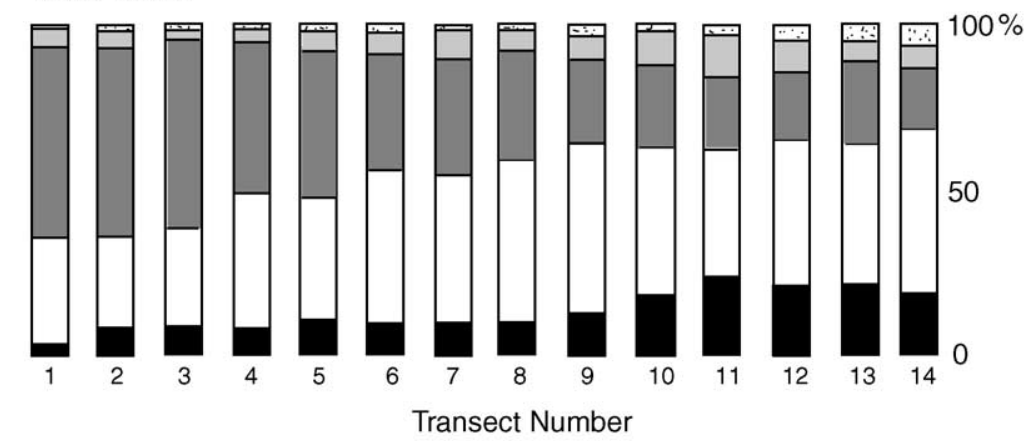

Rounded

$\square$ Subrounded

Subangular

Angular

Very Angular

Fig. 10. Down-glacier changes in roundness of sand size quartz grains on the Rakhiot glacier for (A) supraglacial debris, (B) inner lateral moraine sediments and (C) outer lateral moraine sediments, using the roundness categories of Powers (1953). See Table 2 for Pearson product moment correlation coefficients for quartz sand grain shape versus distance down-glacier, and least-squared regression values. 
gravel and coarse sand ranges being less prominent. The mean size distributions of the Glacier de Cheilon subglacial sediments are very similar to the results obtained by earlier workers.

\subsection{Particle shape and weathering}

The percentage of quartz particles finer than coarse sand for each Zingg shape class for the (A) supraglacial (B) inner lateral and (C) outer lateral debris transport paths of the Rakhiot glacier is shown in Fig. 9. The supraglacial transport results indicate a sharp down-glacier decrease in the equant and blade shape classes and a comparable increase in the tabular and prolate classes. This is true only as far as transect 8 , after which variations are slight in all shape classes, each containing between $20 \%$ and $35 \%$ of the particles. A similar, though slightly gentler gradient is evident in the data for the inner lateral transport path, again with the percentage of blade and equant-shaped particles decreasing and the tabular and prolateshaped particles increasing down-glacier. In this case, the trend continues as far as transect 10 after which the percentages of tabular, blade and prolate-shaped particles vary only slightly with a marginal increase in the equant percentage. The 'cross-over' points on the graphs, marking the decrease of equant and blade shapes and the complementary increase in tabular and prolate classes, occur at a down-glacier point that is similar for both the supraglacial and inner lateral sediments. However, the rate of change is perceptibly greater in the case of the supraglacially transported sediments. Finally, gradients of change in the outer lateral transport path are much weaker than in the supraglacial and inner lateral cases.

The percentages of quartz particles finer than coarse sand for each roundness class for the same three transport paths on the Rakhiot glacier are shown in Fig. 10. The supraglacially transported sediments show an increase in both angular and very angular

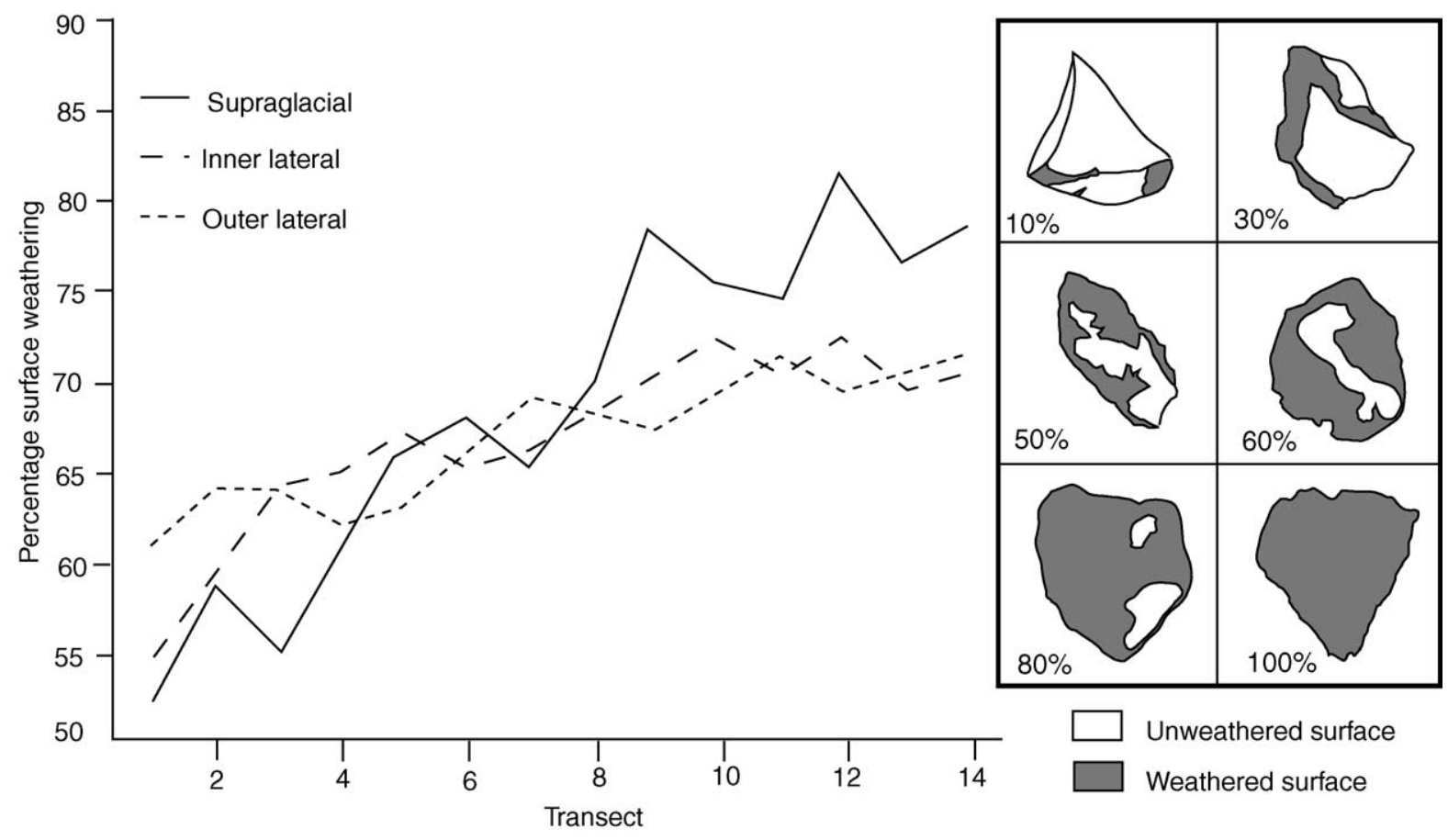

Fig. 11. Down-glacier changes in the surface weathering of sand size quartz grains from the Rakhiot glacier. The percentage surface weathering was estimated using comparative images as shown on the right of the figure (adapted from Sheridan and Marshall, 1987). Least-squared regression values are as follows: supraglacial 0.8815; inner lateral 0.9289; and outer lateral 0.9601 . Pearson product moment correlation coefficients of percentage surface weathering of quartz sand grains versus distance down glacier (transect to transect) are as follows: supraglacial 0.939; inner lateral 0.910; and outer lateral 0.927. 
A

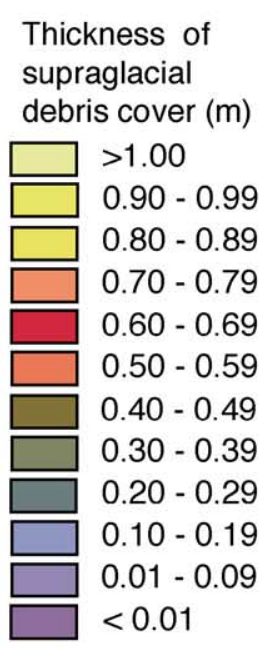

Thickness of supraglacial

debris cover $(\mathrm{m})$

B

Cumulative percentage silt

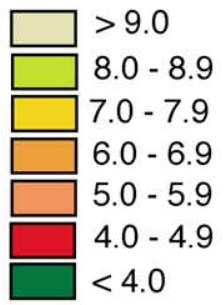

Cumulative percentage sand

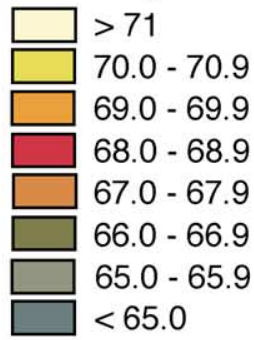

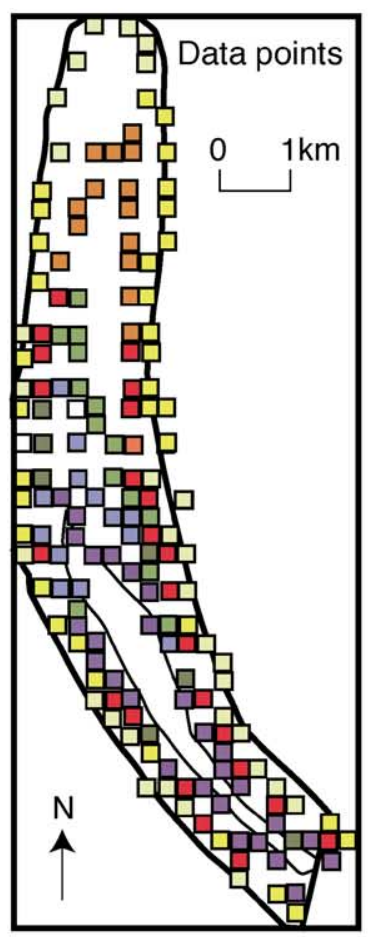
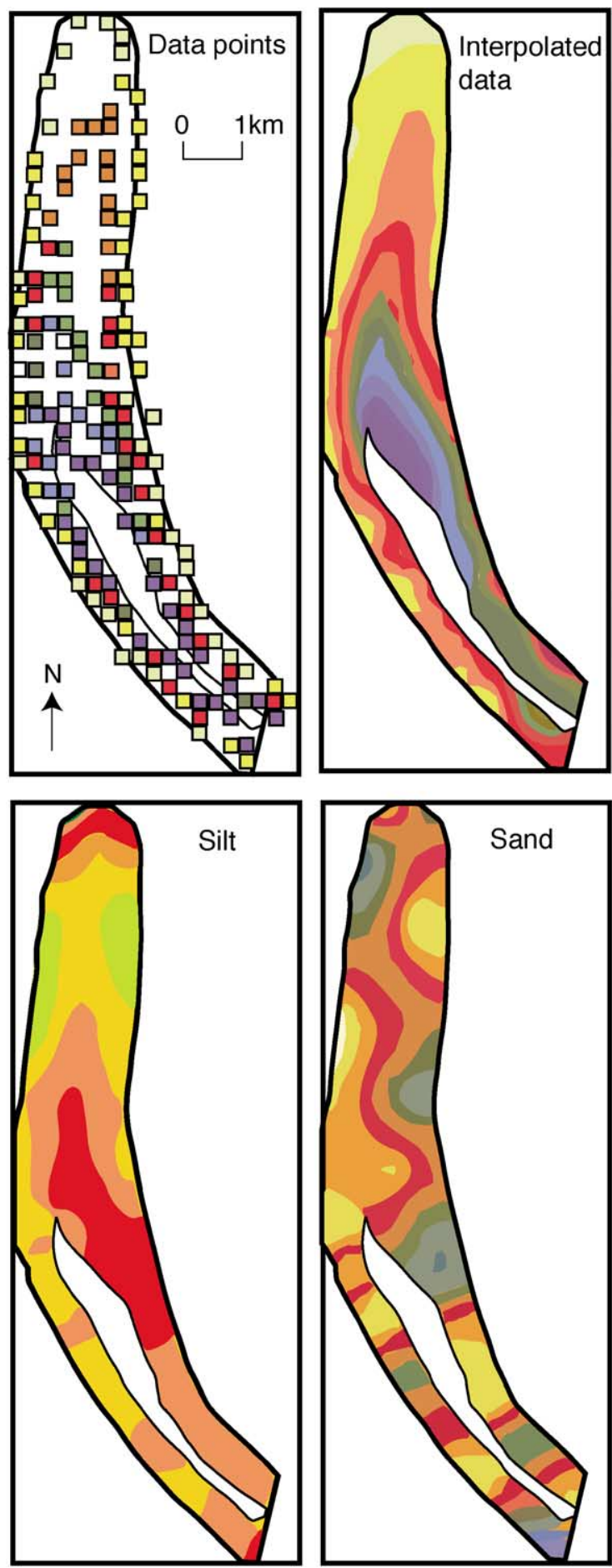

Fig. 12. (A) Thickness of supraglacial debris-cover and (B) percentage silt and sand content of supraglacial debris on the Rakhiot glacier. 
classes (by approximately $30 \%$ and $25 \%$, respectively), with a decline in subangular particles as far as transect 10. Below this point, the percentage of very angular grains remains fairly constant, with some decrease in angular particles and a complementary increase in subrounded and rounded particles.

Along the inner lateral debris path there is a slight increase in the percentage of very angular particles down-glacier as far as transect 11 , but at a lower rate than along the supraglacial path. There is a notable increase in the numbers of angular particle downglacier and a decrease in subangular particles. The percentage of subrounded particles fluctuates slightly, having no obvious down-glacier trend.

The outer lateral deposits show much lower percentages of angular particles in each transect than is the case with the other two transport paths. There is a slight increase in angularity down-glacier as far as transect 9, after which values remain fairly uniform. In contrast, percentages of subangular particle decrease consistently down-glacier, reaching a minimum at transect 9, with a complementary increase in subrounded particles, peaking at the same point. The proportion of rounded particles also shows a slight down-glacier increase.

Estimates of the proportion of weathered surface on sedimentary particles from the three environments (Fig. 11) clearly show a down-glacier increase for all three debris types. The gradient is steepest in the case of the supraglacial sediments, weathered surfaces rising from $51 \%$ at transect 1 to $75 \%$ at transect 11 , and $80 \%$ at transect 12 . The sediments of the inner lateral and outer lateral deposits show similar downglacier increases.

\subsection{Supraglacial debris thickness}

Recently, Bishop et al. (1999) and Shroder et al. (2000) used SPOT imagery to map the surface of the Rakhiot glacier, distinguishing debris-free zones, areas of thin debris on white ice, moisture-laden debris, and thick debris on both topographic 'highs' and 'low'. Furthermore, Shroder et al. (2000) measured the thickness of the supraglacial debris, although they presented data for only one transect. Nevertheless, they were able to show that the thickness of supraglacial sediment in the ablation zone of the Rakhiot glacier is highly variable.
During our fieldwork programme on Nanga Parbat, the thickness of supraglacial debris-cover on the Rakhiot glacier was directly measured (Fig. 12A). The values for percentage silt and percentage sand content in this debris are also shown (Fig. 12B). The greatest thickness was observed at the snout of the glacier and along the margins. Depth to glacier ice decreased towards the central part of the glacier tongue and in an up-glacier direction where debrisfree ice is present. It can be seen that percentage silt content varies longitudinally down-glacier, whereas no clear down-glacier relationship is evident for the values of percentage sand content. Fig. 5 shows the corresponding values for debris-cover thickness, percentage silt and percentage sand content of the supraglacially transported debris along pathways $\mathrm{A}-\mathrm{E}$. The mean values (Fig. 5) indicate a similar trend in the down-glacier increases in debris thickness and percentage silt content. In contrast, the values for percentage sand content bear no obvious relationship to either debris thickness or percentage silt content.

\subsection{Bedrock fractures}

Thin sections of gneiss from all the study areas show that large quartz crystals have hairline cracks indicative of rock fatigue. Such planes of weakness are potential fracture surfaces during stress release, weathering and/or erosion. The frequency of these cracks is such as to yield very small particles $(<100$ $\mu \mathrm{m})$ that are ultimately released as silt-sized grains.

\section{Discussion}

Significant quantities of sand- and silt-size sediments are present within the supraglacial transport paths of high-altitude glaciers in the Nanga Parbat Massif, as the above data show (Table 1; Figs. 4-6). The increased amount of fine-grained sediment in the high-altitude glaciers might be the result of increased down-glacier incorporation of fines from non-glacial sources, including mass-movement and katabatic aeolian transfer, for example. However, such a combination of processes would not be consistent with the enhanced surface weathering effects and the morphological modification of the particles and, in particular, the clear increase in surface weathering of particles 
down-glacier as shown in this study (Figs. 10 and 11). If the fine sediments had been incorporated from nonglacial sources, then the deposits of the inner and outer laterals might reasonably be expected to display essentially similar, if not greater increases in fine sediment content down-glacier because of their proximity to the non-glacial sources. These trends are not evident from our results, and are apparent only in the case of supraglacial transport. A strong correlation between debris thickness and the amount of fine sediment within the debris suggests that the process of fine-grained sediment production is in some way related to the amount of debris transported across the glacier surface.

A down-glacier increase in the supply of fine sediments from subglacial sources to the supraglacial environment offers another, alternative explanation of the observed fining of the supraglacial sediments. However, it is very difficult to remove from the ice fine sediment diffused along grain boundaries. Nevertheless, if subglacial sediments were to become entrained within a supraglacial meltwater system on a Nanga Parbat glacier, given the characteristically rapid, but short distance meltwater flow into any of the abundant crevasses, it is unlikely that such sediment would be deposited in the supraglacial environment. Any exposed subglacial sediment entrained by supraglacial streams would more likely be washed back into the glacier rather than transported into and across the glacier surface. Furthermore, supraglacial streams and moulins, though ephemeral, tend to recur in the same places over many years. Thus, should subglacial sediments be deposited at the glacier surface, their distribution would tend to be quite localized. Taken together, these observed mechanisms in the Nanga Parbat glaciers suggest that down-glacier fining of supraglacial sediment by increased supply from subglacial sources is unproven, and probably unlikely.

Studies of glacial sediment production have shown that fine-grained sediments are essentially products of abrasion (Iverson, 1995; Benn and Evans, 1998). Inter-clast abrasion may be enhanced when a thick debris mantle is present on an unstable, downwasting glacier surface. Debris movement over uneven glacier surfaces is characterized by high velocities down very steep gradients, resulting in a notable degree of interclast contact. The resulting localized stressing of the grains, if sustained, causes significant abrasion of particle surfaces, especially on corners and edges. The likely products are silt- to sand-sized daughter fragments, with only a slight reduction in the size of the parent fragments (Crabtree et al., 1964; Haldorsen, 1981). In this way, supraglacial debris tends to retain its essentially coarse nature, with fine-grained sediments continually produced and retained, in part, as an integral fraction of this sediment.

Assuming such a process of fine particle production, the great thickness of surface debris on the Nanga Parbat glaciers implies the existence of many clast-on-clast contact points. Such localized stress enhancement increases the amount of abrasion, more fine particles being produced when point contacts are abundant. Any increase in the thickness of this debris mantle enhances the number of clast-on-clast contacts, and thus raises the potential for fine-grained sediment production. In addition, the likelihood of inter-clast abrasion within the supraglacial environment increases with input of angular debris from adjacent rock walls, angular fragments being more susceptible to abrasion than rounded ones.

The large boulders present within the debriscover also increase the potential for fine sediment production, as these are capable of generating considerable inter-particle stresses. For the same reason, large boulders are also important in the crushing of debris within the supraglacial environment. Using an example from the Glacier du Miage in the Italian Alps, Benn and Evans (1998) have shown how grain crushing occurs at inter-boulder contacts in the supraglacial and englacial environments. The movement of debris in the supraglacial zone is active because of the irregular nature of the ice surface, the steep ice gradients, and the rapidity of glacier movement. It is believed that the products of crushing are coarser than those arising from abrasion. Boulton (1978) estimated that the size range distribution curve of fragments produced by these two processes in the glacial environment has an inflection at about $0.5 \mathrm{~mm}$, the crushing products being coarser, and the abrasion products finer. However, these boundary values do not take account of local factors such as ease of debris particle fracture and the intensity of the crushing process. Any increase in the role of such factors may cause the size range of fragments produced by 
crushing to extend into the silt range (Haldorsen, 1981).

The area of supraglacial debris is large, so that the potential of both physical and chemical processes to break up and decompose the debris in this environment is considerable. Furthermore, continued downglacier movement of debris exposes fresh debris particle surfaces to the weathering processes. The extent to which weathering breaks down large fragments to produce fine-grained sediments is contentious, and this particular environment provides no unequivocal evidence as to the nature of such weathering. However, the many split boulders to be seen on the surface of the Nanga Parbat glaciers point towards supraglacial weathering and erosion. This provides prima facie grounds for regarding supraglacial debris as a source of fine sediment.

Thick debris mantles on Himalayan glaciers provide some protection from ablation (Hewitt, 1989), but melting may occur on any newly exposed parts of the glacier that have lost their debris-cover as a consequence of ice movement or debris sliding. Meltwater draining from exposed ice surfaces flows into well-developed crevasse systems or joins supraglacial streams to reach the glacier margins. In this way, finegrained sediment is removed from the supraglacial zone and transported to both basal and ice-marginal zones. Evidence of such preferential transport of finegrained sediment is provided by the concentration of fine-grained debris in the supraglacial meltwater channels seen at the margins of the supraglacial zone. These deposits suggest that more fine-grained sediments form in the supraglacial zone than have generally been observed because fine-grained sediment is rapidly removed by surficial meltwater. Much of this meltwater, rich in finer materials, descends to the basal zone of the glacier where the finer grades in suspension may, in turn, be incorporated into those produced in the basal zone. Such incorporation of supraglacially scoured sediments within the basal zone may thus obscure their origin as supraglacial fines.

Of course, direct observation of all stages of this process is not possible. However, the convergence of evidence derived from observation of ice surface translocation of material, and the distinctive particlesize characteristics of all facies associated with the Nanga Parbat glaciers, suggests that the mechanisms outlined here (acting together in a variety of combinations) may have general validity in Himalayan glacial transport systems.

The results presented here indicate that there is convergence of glacial debris transport pathways towards the glacier snout as a result of the upward transfer of subglacial debris by compressive ice flow and/or elevation along medial moraines sourced above the firn line, and the downward transfer of supraglacial debris by mass movement and meltwater processes. The considerable variability in the shape of sand grains shows that mixing of debris occurs down-glacier of transects 11 (Figs. 9 and 10). The abundant meltwaters present at the glacier snout serve to deplete the surface sediments of fines, as shown by the values for percentage silt and sand content below transect 11 (Fig. 5). Analysis of terminal zone sediments indicates that meltwater effects a concentration of fine sediments in the basal zone. Sediments of the proglacial zone are rich in silt (Table 1), suggesting preferential transport of fines by meltwaters, through and away from this zone, or by concentration into lacustrine accumulations. The coarser debris is not transferred to the proglacial zone, but remains in the terminal zone as part of the residual glacial deposits.

Those sediments produced above the glacier margins yield results suggesting that notable proportions of fine-grained sediments can be released by exogenetic weathering of the bare rock walls above the glaciers. The values obtained in this study (Fig. 7 and Table 1) are for proportions of the fine-grained sediments only; they are not proportions of the total debris produced by rock wall weathering, for these would include considerable volumes of large rock fragments. As such, the results are not a true indicator of the actual proportion of fine-grained sediment produced by bedrock weathering. However, they do provide an indication of the great volumes of fine-grained sediment that can be produced. They are also a confirmation that weathering in these systems releases fine sediments that then become incorporated into the mountain environment sedimentary systems.

Gomez et al. (1988) showed that the surface texture of quartz grains may be largely controlled by the microstructures within quartz grains arising from the tectonic history of the rock. The existence of many silt-sized particles with fresh, unweathered faces and 
sharp, angular edges, however, indicates that these particles were formed by breakout from bedrock rather than by weathering of larger fragments. Features such as weathered faces and blunted edges (Eyles, 1978), expectable products of the latter process, are generally absent here, suggesting that silt-sized fine particles are formed by the physical breakdown of bedrock in the non-glacial environment.

Observations made on thin sections of bedrock taken from both Himalayan and Alpine study areas indicate the condition of the bedrock and the sizes of the constituent mineral particles likely to result from its comminution. The particle sizes within this bedrock include grains as small as silt and sand formed by the hairline cracks that cut across some mineral grains. Two obvious inferences follow from this. First, in order for the cracks to form, the minerals in the bedrock must have suffered fatigue. Second, any future weathering and breakdown of this bedrock will yield fine particles. In the Nanga Parbat massif the rocks were endogenetically stressed during unloading of the massif (Zeitler et al., 1993, 2001), a history consistent with the presence of such cracks. Such conditions may also have prevailed in the Mt. Blanc de Cheilon massif. It might also be argued that bedrock fatigue may well have taken place beneath the great thicknesses of ice associated with the Pleistocene ice advances (Small, 1983). Following glacier recession and downwasting, exposed rock walls are highly susceptible to exogenetic weathering (Small, 1983 op. cit.). The existence of the rock fatigue features described here supports the view that defects within quartz particles exert a strong influence upon rock disintegration (Moss et al., 1973; Gomez et al. 1988; Assalay et al. 1998). Such stressed bedrock containing microcracks is more susceptible than unstressed rock to the intense geomorphic activity characteristic of the high-altitude Himalayan environment. The nature of the bedrock and the presence of extensive exposures of bare rock-wall above the glaciers of the Nanga Parbat Massif provide abundant opportunity for surface processes to attack the bedrock and produce debris ranging from silt-sized particles to large boulders. In the European Alps above the Glacier de Cheilon, the slopes are neither as high nor as extensive as those above the Nanga Parbat glaciers. It may be inferred that the periglacial processes, particularly weathering and mass movement, may not be as important in providing sediment to the Glacier de Cheilon as they are on Nanga Parbat.

The results presented here support the view that weathering of bedrock by subaerial processes is capable of producing fine sediments together with large blocks (Nahon and Trompette, 1982; Minervin, 1984; Blatt, 1987; Konischev, 1987; Ritter and Mazzullo, 1990). As mentioned above, Hewitt (1988) also showed that substantial amounts of silty-sand (between 15\% and 35\%) are produced when large rock avalanches occur. Such observations have clear relevance to the sedimentary systems of the Nanga Parbat Massif, as the debris produced on the high rock walls is a major source of debris for the fluvial, glacial and mass movement systems. In contrast to earlier views emphasizing input of large boulders and scree, it appears that a broad range of sedimentary particles down to silt size enters the sedimentary systems in this geomorphologically dynamic region with its tectonically stressed bedrock. Most recent workers have explained the presence of fine-grained sediments in the glacial system in terms of the high stresses characteristic of the subglacial zone of traction. However, the role of subaerial sites as significant sources of these fine sediments in some high-altitude glacial systems should be incorporated into revised theories of glacial sediment production.

The magnitude of such input cannot yet be quantified, but it appears to be substantial in the Nanga Parbat Massif. It is suggested that, because such finegrained sediments are so readily transported and mixed, subaerial processes have played a more important role in the denudational history of such tectonically active, glaciated areas than has been recognized hitherto.

The down-glacier increase in the percentage of sand and silt (Figs. 4-6), together with modification of sediment particle morphology in the same direction (Figs. 9-11), suggests that the supraglacial transport system is not passive in the high-altitude glaciers in this particular geological setting. On the contrary, such trends suggest that particle comminution is the prevailing mechanism. However, other mechanisms such as aeolian sedimentation with particles derived from weathered bedrock, moraines and other landforms may also contribute to the 
supraglacial sediment. The amount of fine-grained sediment produced in the European system used here for comparison (the Glacier de Cheilon) is significantly less than that found on the Nanga Parbat glaciers (Table 1). This suggests that supraglacial sediment comminution is of lesser importance in the process of sediment production in lower-altitude alpine and/or glaciers that lack a thick supraglacial debris cover and in a less dynamic geomorphic setting than in the Himalaya.

\section{Conclusion}

Significant quantities of sand- and silt-size sediments are present within the supraglacial transport paths of high-altitude debris-mantled glaciers in the Nanga Parbat Massif. The increase in the percentage of sand and silt down-glacier, together with the down-glacier modification of sediment particle morphology, suggests that supraglacial transport in highaltitude glaciers results in particle comminution. In cases in which supraglacial debris is less voluminous, as in typical alpine glaciers such as the Glacier de Cheilon (Swiss Alps), fine-grained sediment production by supraglacial abrasion, weathering and glaciofluvial action is less important. While currently favoured theories of sediment production are consistent with evidence from alpine glaciers with less abundant supraglacial debris, in which finer sediment is predominantly associated with the basal zones of glaciers, the processes of sediment production operating in the high-altitude glacial systems such as those described here are significantly different. Here, fine-grained sediment is demonstrably important in the supraglacial zone. It is thus concluded that substantial volumes of fine sediments are generated outside the basal zone of high-altitude debris-covered glaciers in low to middle latitudes.

\section{Acknowledgements}

The Natural Environment Research Council (Award GT4/89/GS/053) funded the work on which this paper is based. We would like to thank Kim Lee (University of California at Riverside, USA) for drafting most of the figures, and Dr. Dougie Benn (University of Aberdeen, UK), Professor John Menzies (Brock University, Canada), Dr. David J.A. Evans (University of Glasgow) and Dr. Martin P. Kirkbride (University of Aberdeen) for their detailed and helpful reviews of an earlier version of this paper.

\section{References}

Allen, T., 1981. Particle Size Measurement, 3rd edn. Chapman \& Hall, London, 678 pp.

Assalay, A.M., Rogers, C.D.F., Smalley, I.J., Jefferson, I.F., 1998. Silt: 2-62 $\mu \mathrm{m}, 9-4 \phi$. Earth Science Reviews 45, 61-88.

Benn, D.I., Ballantyne, C.K., 1993. The description and representation of particle shape. Earth Surface Processes and Landforms $18,665-672$.

Benn, D.I., Ballantyne, C.K., 1994. Reconstructing the transport history of glacigenic sediments: a new approach based on co-variance of clast form indices. Sedimentary Geology 91, 215-227.

Benn, D.I., Evans, D.J.A., 1998. Glaciers and Glaciation Arnold, London, 734 pp.

Bishop, M.P., Shroder, J.F., Hickman, B.L., 1999. SPOT panchromatic imagery and neural networks for information extraction in a complex mountain environment. Geocarto International 14, $17-26$.

Blatt, H., 1987. Oxygen isotopes and the origin of quartz. Journal of Sedimentary Petrology 57, 373-377.

Blikra, L.H., Nemec, W., 1998. Postglacial colluvium in western Norway: depositional processes, facies and palaeoclimatic record. Sedimentology 45, 909-959.

Boulton, G.S., 1971. Till genesis and fabric in Svalbard, Spitsbergen. In: Goldthwait, R.P. (Ed.), Till: A Symposium. Ohio State Univ. Press, Columbus, pp. 41-72.

Boulton, G.S., 1978. Boulder shapes and grain-size distributions of debris as indicators of transport paths through a glacier and till genesis. Sedimentology 25, 773-799.

Brunsden, D., Jones, D.K.C., 1984. The geomorphology of high magnitude-low frequency events in the Karakoram mountains. In: Miller, K.J. (Ed.), The International Karakoram Project, vol. I. Cambridge Univ. Press, Cambridge, pp. 383-388.

Crabtree, D.D., Kinasevich, R.S., Mular, A.L., Meloy, T.P., Fuerstenau, D.W., 1964. Mechanisms of size reduction in comminution systems: Part I. Impact, Abrasion and Chipping grinding. Transactions of the American Society of Mining Engineers 229, 201-210.

Dowdeswell, J.A., Hambrey, M.J., Wu, R., 1985. A comparison of clast fabric and shape in late Precambrian and modern glacigenic sediments. Journal of Sedimentary Petrology 55, 691-704.

Escher, A., Masson, H., Steck, A., 1993. Nappe geometry in the western Swiss Alps. Journal of Structural Geology 15, 501-509.

Eyles, N., 1978. Scanning electron microscopy and particle size analysis of debris from a British Columbian glacier: a comparative report. In: Whalley, W.B. (Ed.), Scanning Electron Micro- 
scopy in the Study of Sediments. Geo Abstracts, Norwich, pp. $4-14$.

Eyles, N. (Ed.), 1983. Glacial Geology-An Introduction for Engineers and Earth Scientists. Pergamon, Oxford, 409 pp.

Finsterwalder, R., 1937. Die Gletscher des Nanga Parbat: glaziologishe arbeiten der deutschen Himalaya-Expedition 1934 und ihre Ergebnisse. Zeitschrift für Gletscherkunde 25, 57-108.

Furbish, D.J., Andrews, J.T., 1984. The use of hypsometry to indicate long-term stability and response of valley glaciers to changes in mass transfer. Journal of Glaciology 30, 199-211.

Gale, S.J., Hoare, P.G., 1991. Quaternary Sediments. Halsted Press, New York, 323 pp.

Gardner, J.S., 1985. Snow and Ice Hydrology Project Annual Report. University of Waterloo, Canada, 180-192.

Gardner, J.S., Jones, N.K., 1993. Sediment transport and yield at the Raikot Glacier, Nanga Parbat, Punjab Himalaya. In: Shroder, J.F. (Ed.), Himalaya to the Sea. Routledge, London, pp. 184-197.

Gomez, B., Dowdeswell, J.A., Sharp, M., 1988. Microstructural control of quartz sand grain shape and texture: implications for the discrimination of debris transport pathways through glaciers. Sedimentary Geology 57, 119-129.

Goudie, A.S., 1984. Salt efflorescences and salt weathering in the Hunza valley, Karakoram Mountains, Pakistan. In: Miller, K.J. (Ed.), The International Karakoram Project. Cambridge Univ. Press, Cambridge, pp. 607-615.

Haldorsen, S., 1981. Grain-size distribution of subglacial till and its relation to subglacial crushing and abrasion. Boreas 10, 91-105.

Hewitt, K., 1988. Catastrophic landslide deposits in the Karakoram Himalaya. Science 242, 64-67.

Hewitt, K., 1989. The altitudinal organisation of Karakoram geomorphic processes and depositional environments. Zeitschrift für Geomorphologie 76, 9-32.

Humlum, O., 1978. Genesis of layered lateral moraines, implications for palaeoclimatology and lichenometry. Geografisk Tidsskrift Bd. 77, 65-72.

Iverson, N.R., 1995. Processes of glacial erosion. In: Menzies, J. (Ed.), Glacial Environments, vol. 1. Modern Glacial Environments-Processes, Dynamics and Sediments. Butterworth-Heinemann, Oxford, pp. 241-257.

Kick, W., 1962. Variations of some central Asiatic Glaciers. Variations of the Regime of Existing Glaciers. Commission of Snow and Ice. IAHS Publication, vol. 58, pp. 223-229.

Kirkbride, M.P., 1995. Processes of transportation. In: Menzies, J. (Ed.), Glacial Environments, vol. 1. Modern Glacial Environments-Processes, Dynamics and Sediments. Butterworth-Heinemann, Oxford, pp. 261-292.

Kirkbride, M.P., Spedding, N., 1996. The influence of englacial drainage on sediment transport pathways and till texture of temperate valley glaciers. Annals of Glaciology 22, 317-327.

Konischev, V.N., 1987. Origin of loess-like silt in Northern Jakutia, USSR. GeoJournal 15, 135-139.

Krüger, L., 1994. Glacial processes, sediments, landforms and stratigraphy in the terminus region of Myrdalsjökull, Iceland. Folia Geographica Danica 21, 233.

Lautridou, J.-P., 1988. Recent advances in cryogenic weathering. In: Clark, M.J. (Ed.), Advances in Periglacial Geomorphology. Wiley, Chichester, pp. 33-47.
Lautridou, J.-P., Ozouf, J.C., 1984. Experimental frost shattering. 15 years of research at the Centre de Geomorphologie du CNRS. Progress in Physical Geography 6, 217-232.

Lindholm, R., 1987. A Practical Approach to Sedimentology. Allen \& Unwin, London, $276 \mathrm{pp}$.

Matthews, J.A., Petch, J.R., 1982. Within-valley asymmetry and related problems of Neoglacial lateral moraine development at certain Jotunheimen glaciers, southern Norway. Boreas 11, $225-247$.

McGreevy, J.P., Whalley, W.B., 1982. The geomorphic significance of rock temperature variations in cold climates: a discussion. Arctic and Alpine Research 14, 157-162.

Minervin, A.V, 1984. Cryogenic processes in Loess formation in Central Asia. In: Velichko, A.A. (Ed.), Late Quaternary Environments of the Soviet Union. Longman, London, pp. 133-140.

Moss, A.J., 1966. Origin, shaping and significance of quartz sand grains. Journal of the Geological Society of Australia 13, $97-136$.

Moss, A.J., Walker, P.H., Hutka, J., 1973. Fragmentation of granitic quartz in water. Sedimentology 20, 489-511.

Nahon, D., Trompette, R., 1982. Origin of siltstones: glacial grinding versus weathering. Sedimentology 29, 25-35.

Pillewizer, W., 1956. Der Rakhiot Gletscher am Nanga Parbat im Jahre 1954. Zeitschrift für Gletscherkunde und Glazialgeologie 3, $181-194$.

Powers, M.C., 1953. A new roundness scale for sedimentary particles. Journal of Sedimentary Petrology 23, 117-119.

Ritter, C., Mazzullo, J., 1990. Control of sediment source on the morphology of glacial quartz grains. 13th International Sedimentology Conference, Abstracts Volume, 342-343.

Roh, P.-D., Rey, Ch., 1989. Les marais de l'Essertse. In: Heremence, V.S. (Ed.), Bulletin de la Murithienne, vol. 107, pp. $167-185$.

Seeber, L., Picher, A., 1998. Strain partitioning along the Himalayan arc and the Nanga Parbat antiform. Geology 26 (9), 791-794.

Sheridan, M.F., Marshall, J.R., 1987. Comparative charts for quantitative analysis of grain textural elements on pyroclastics. In: Marshall, J.R. (Ed.), Clastic Particles. Van Nostrand-Reinhold, New York, pp. 98-121.

Shroder, J.F., Bishop, M.P., Copland, L., Sloan, V.F., 2000. Debriscovered glaciers and rock glaciers in the Nanga Parbat Himalaya, Pakistan. Geografiska Annaler 82A, 17-31.

Small, R.J., 1983. Lateral moraines of Glacier de Tsidjiore Nouve: form, and implications. Journal of Glaciology 29 (102), 250-259.

Smalley, I.J., 1990. Possible formation mechanisms for the modal coarse-silt quartz particles in loess deposits. Quaternary International 7/8, 23-27.

Starkel, L., 1972. The role of catastrophic rainfall in the shaping of the relief of the lower Himalaya. Geographica Polonica 21, 103-143.

Wentworth, C.K., 1922. A scale of grade and class terms for clastic sediments. Journal of Geology 30, 377-392.

Whalley, W.B., 1984. High altitude rock weathering processes. In: Miller, K.J. (Ed.), International Karakoram Project. Cambridge Univ. Press, Cambridge, pp. 366-373.

Wheeler, J., Treloar, P., Potts, G., 1995. Structural and metamorphic 
evolution of the Nanga Parbat syntaxis, Pakistan Himalayas, on the Indus gorge transect: the importance of early events. Geological Journal 30, 349-371.

Zeitler, P.K., Chamberlain, C.P., Smith, H.A., 1993. Synchronous anatexis, metamorphism, and rapid denudation at Nanga Parbat (Pakistan Himalaya). Geology 21, 347-350.
Zeitler, P.K., Meltzer, A.S., Koons, P.O., Craw, D., Hallet, B., Chamberlain, C.P., Kidd, W.S.F., Park, S.K., Seeber, L., Bishop, M., Shroder, J., 2001. Erosion, Himalayan geodynamics and the geomorphology of metamorphism. GSA Today 11 (1), 4-9.

Zingg, T., 1935. Beitrag zur Schotteranalyse, Scweizerische. Mineralogische und Petrographische Mitteilungen 15, 39-140. 